\title{
Synthesis, Characterization, and Application of Segphos Derivative Having Diferrocenylphosphino-Donor Moieties
}

\author{
Hao Hu, ${ }^{\dagger, \ddagger}$ Hiroki Ichiryu,${ }^{\dagger}$ Naoki Seki,${ }^{\dagger}$ Kiyohiko Nakajima, ${ }^{\S}$ \\ Yasuhiro Ohki,\|l and Masamichi Ogasawara*,
}

\begin{abstract}
${ }^{\dagger}$ Department of Natural Science, Graduate School of Science and Technology and Research Cluster on "Innovative Chemical Sensing", Tokushima University, Tokushima 770-8506, Japan. $\quad$ Graduate School of Life Science, Hokkaido University, Kita-ku, Sapporo 001-0021, Japan. Department of Chemistry, Aichi University of Education, Igaya, Kariya, Aichi 448-8542, Japan. "Department of Chemistry, Graduate School of Science, Nagoya University, Furo-cho, Chikusa-ku, Nagoya 464-8602, Japan.
\end{abstract}

\section{Supporting Information}

\section{Table of Contents}

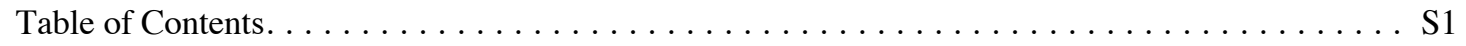

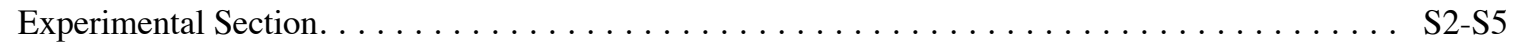

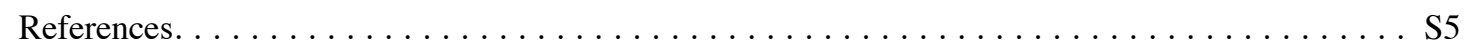

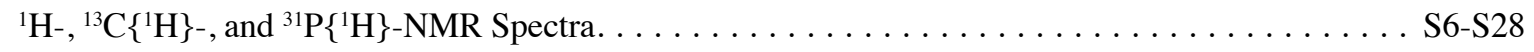

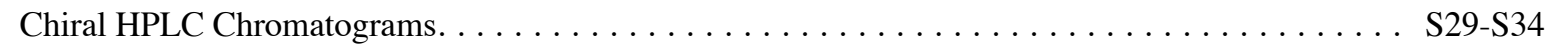




\section{Experimental Section.}

General. All anaerobic and/or moisture sensitive manipulations were carried out with standard Schlenk techniques under predried nitrogen or with glovebox techniques under prepurified argon. ${ }^{1} \mathrm{H}$ NMR (at 400 $\mathrm{MHz}$ ) and ${ }^{13} \mathrm{C}$ NMR (at $101 \mathrm{MHz}$ ) chemical shifts are reported in ppm downfield of internal tetramethylsilane. ${ }^{31} \mathrm{P}$ NMR (at $162 \mathrm{MHz}$ ) chemical shifts are externally referenced to $85 \% \mathrm{H}_{3} \mathrm{PO}_{4}$. Tetrahydrofuran and toluene were distilled from benzophenone-ketyl under nitrogen prior to use. Chloroform- $d$ was distilled from $\mathrm{P}_{2} \mathrm{O}_{5}$

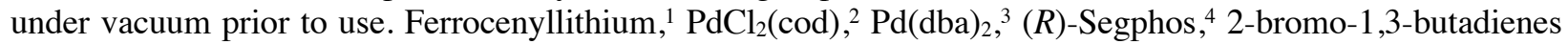
$\left(\mathbf{5 a},{ }^{5} \mathbf{5 b},{ }^{6} \mathbf{5} \mathbf{c},{ }^{7} \mathbf{5 d},{ }^{8} \mathbf{5 e}^{9}\right)$ were prepared as reported. All the other chemicals were obtained from commercial sources and used as received unless otherwise noted.

Chlorodiferrocenylphosphine. ${ }^{10}$ A solution of ferrocenyllithium $(16.8 \mathrm{~g}, 87.5 \mathrm{mmol})$ in THF (200 mL) was cooled to $0{ }^{\circ} \mathrm{C}$, and to this was added (diethylamino)dichlorophosphine $(6.06 \mathrm{~g} ; 34.8 \mathrm{mmol})$ dropwise. After stirring the mixture overnight at room temperature, the reaction progress was monitored by ${ }^{31} \mathrm{P}-\mathrm{NMR}$. Remaining ferrocenyllithium was quenched with a small amount of water and the volatiles were removed under vacuum. The residue was extracted with hot hexane and filtered through a pad of Celite. Removal of hexane and ferrocene under reduced pressure at $60^{\circ} \mathrm{C}$ gave dark red oil (ca. $18 \mathrm{~g}$ ). The red oil was dissolved in dry toluene $(120 \mathrm{~mL})$ and to this was added excess phosphorus trichloride (ca. $10 \mathrm{~g}$, ca. $73 \mathrm{mmol}$ ). The solution was stirred for $1 \mathrm{~h}$ at $50{ }^{\circ} \mathrm{C}$. All the volatiles were removed under reduced pressure at $60{ }^{\circ} \mathrm{C}$. The residue was recrystallized from toluene to give a yellow solid. Yield: $13.6 \mathrm{~g}(31.2 \mathrm{mmol} ; 90 \%) .{ }^{1} \mathrm{H}$ NMR $\left(\mathrm{CDCl}_{3}\right): \delta 4.20(\mathrm{~s}, 10 \mathrm{H}), 4.28-4.53(\mathrm{~m}, 8 \mathrm{H}) .{ }^{31} \mathrm{P} \mathrm{NMR}\left(\mathrm{CDCl}_{3}\right): \delta 81.2$.

Benzo-1,3-dioxol-5-yldiferrocenylphosphine oxide (2). To a stirring suspension of magnesium turnings $(885 \mathrm{mg}, 36.4 \mathrm{mmol})$ in THF $(10 \mathrm{~mL})$ was added a THF $(75 \mathrm{~mL})$ solution of 5-bromo-1,3-benzodioxole $(7.25$ $\mathrm{g}, 36.3 \mathrm{mmol}$ ) dropwise via a cannula, and the mixture was stirred for $4 \mathrm{~h}$ at $50{ }^{\circ} \mathrm{C}$. The flask was cooled with ice-water and to this was added a THF $(50 \mathrm{~mL})$ solution of chlorodiferrocenylphosphine $(10.5 \mathrm{~g}, 24.1 \mathrm{mmol})$ dropwise, then the mixture was stirred at room temperature overnight. The reaction mixture was quenched with a small amount of water, then evaporated to dryness. The residue was suspended in dichloromethane (ca. 100 $\mathrm{mL}$ ) and to this was added aqueous $\mathrm{H}_{2} \mathrm{O}_{2}$ dropwise until the complete oxidation of the phosphine (checked by TLC). The organic layer was washed with water and brine, dried over $\mathrm{MgSO}_{4}$, filtered, and evaporated. The residue was purified by silica gel chromatography (with benzene/acetone $=2 / 1$ ) to give a yellow solid. Yield: $8.16 \mathrm{~g}(15.2 \mathrm{mmol} ; 63 \%) .{ }^{1} \mathrm{H} \mathrm{NMR}\left(\mathrm{CDCl}_{3}\right): \delta 4.20-4.21(\mathrm{~m}, 2 \mathrm{H}), 4.24(\mathrm{~s}, 10 \mathrm{H}), 4.37-4.39(\mathrm{~m}, 2 \mathrm{H}), 4.40-4.42$ $(\mathrm{m}, 4 \mathrm{H}), 6.02(\mathrm{~s}, 2 \mathrm{H}), 6.92(\mathrm{dd}, J=7.8$ and $2.3 \mathrm{~Hz}, 1 \mathrm{H}), 7.11(\mathrm{dd}, J=11.5$ and $1.2 \mathrm{~Hz}, 1 \mathrm{H}), 7.36(\mathrm{ddd}, J=12.4$, 7.8 , and $1.2 \mathrm{~Hz} 1 \mathrm{H}) .{ }^{13} \mathrm{C} \mathrm{NMR}\left(\mathrm{CDCl}_{3}\right): \delta 69.6,70.8\left(\mathrm{~d}, J_{\mathrm{PC}}=10.5 \mathrm{~Hz}\right), 71.1\left(\mathrm{~d}, J_{\mathrm{PC}}=13.7 \mathrm{~Hz}\right), 71.4\left(J_{\mathrm{PC}}=10.5\right.$ $\mathrm{Hz}), 72.3\left(J_{\mathrm{PC}}=12.9 \mathrm{~Hz}\right), 75.3\left(\mathrm{~d}, J_{\mathrm{PC}}=120.1 \mathrm{~Hz}\right), 101.4,108.2\left(J_{\mathrm{PC}}=14.7 \mathrm{~Hz}\right), 110.7\left(J_{\mathrm{PC}}=12.8 \mathrm{~Hz}\right), 126.2$ $\left(J_{\mathrm{PC}}=10.1 \mathrm{~Hz}\right), 128.5\left(\mathrm{~d}, J_{\mathrm{PC}}=112.6 \mathrm{~Hz}\right), 147.4\left(J_{\mathrm{PC}}=17.9 \mathrm{~Hz}\right), 150.1\left(J_{\mathrm{PC}}=2.7 \mathrm{~Hz}\right) .{ }^{31} \mathrm{P} \mathrm{NMR}\left(\mathrm{CDCl}_{3}\right): \delta$ 29.4. ESI-HRMS Calcd for $\mathrm{C}_{27} \mathrm{H}_{24} \mathrm{Fe}_{2} \mathrm{O}_{3} \mathrm{P}(\mathrm{M}+1)$ : 539.0162. Found: 539.0163 .

Fc-Segphos Dioxide (3). To a solution of $2(6.50 \mathrm{~g}, 12.1 \mathrm{mmol})$ in THF (20 mL) was added an LTMP solution, which was prepared from 2,2,6,6-tetramethylpiperidine $(2.75 \mathrm{~g}, 19.5 \mathrm{mmol})$ and ${ }^{n} \mathrm{BuLi}(1.70 \mathrm{M}$ hexane solution, $11.0 \mathrm{~mL}, 18.7 \mathrm{mmol})$ in THF $(12 \mathrm{~mL})$, at $-15{ }^{\circ} \mathrm{C}$ and the mixture was stirred at this temperature for $1 \mathrm{~h}$. The mixture was added to a suspension of $\mathrm{FeCl}_{3}(2.96 \mathrm{~g}, 18.2 \mathrm{mmol})$ in a THF (20 $\mathrm{ml}) /$ toluene $(20 \mathrm{~mL})$ mixture at $0{ }^{\circ} \mathrm{C}$, then the whole mixture was stirred overnight at room temperature. After evaporation of the solvent, the residue was dissolved in $\mathrm{CH}_{2} \mathrm{Cl}_{2}$. The organic layer was washed with dil. $\mathrm{HCl}$ and water successively, dried over $\mathrm{MgSO}_{4}$, filtered, then evaporated to dryness. The crude product was purified by silica gel chromatography (with benzene/acetone $=2 / 1)$ to give a yellow solid. Yield: $3.26 \mathrm{~g}(3.03$ mmol; 50\%). ${ }^{1} \mathrm{H}$ NMR $\left(\mathrm{CDCl}_{3}\right): \delta 4.12(\mathrm{br}, 2 \mathrm{H}), 4.18(\mathrm{~s}, 10 \mathrm{H}), 4.24(\mathrm{br}, 2 \mathrm{H}), 4.29(\mathrm{br}, 2 \mathrm{H}), 4.35$ (br, 2H), 4.41 (s, 12H), 4.47(br, 2H), $4.61(\mathrm{br}, 2 \mathrm{H}), 5.71(\mathrm{br}, 2 \mathrm{H}), 5.95(\mathrm{~d}, J=1.6 \mathrm{~Hz}, 2 \mathrm{H}), 5.97(\mathrm{~d}, J=1.6 \mathrm{~Hz}, 2 \mathrm{H}), 6.75(\mathrm{dd}$, $J=8.0$ and $2.0 \mathrm{~Hz}, 2 \mathrm{H}), 6.97(\mathrm{dd}, J=15.6$ and $8.0 \mathrm{~Hz}, 2 \mathrm{H}) .{ }^{13} \mathrm{C} \mathrm{NMR}\left(\mathrm{CDCl}_{3}\right): \delta 69.4(\mathrm{~d}, J=10.1 \mathrm{~Hz}), 69.48$, $69.52,70.3\left(\mathrm{~d}, J_{\mathrm{PC}}=9.7 \mathrm{~Hz}\right), 70.7\left(\mathrm{~d}, J_{\mathrm{PC}}=9.9 \mathrm{~Hz}\right), 71.6\left(J_{\mathrm{PC}}=12.0 \mathrm{~Hz}\right), 71.7\left(J_{\mathrm{PC}}=11.7 \mathrm{~Hz}\right), 71.9\left(J_{\mathrm{PC}}=10.6\right.$ $\mathrm{Hz}), 74.0\left(J_{\mathrm{PC}}=13.6 \mathrm{~Hz}\right), 74.7\left(J_{\mathrm{PC}}=12.7 \mathrm{~Hz}\right), 78.2\left(J_{\mathrm{PC}}=118.2 \mathrm{~Hz}\right), 79.7\left(J_{\mathrm{PC}}=119.3 \mathrm{~Hz}\right), 101.0,107.1(\mathrm{~d}$, $\left.J_{\mathrm{PC}}=16.2 \mathrm{~Hz}\right), 119.7\left(\mathrm{dd}, J_{\mathrm{PC}}=8.6\right.$ and $\left.3.0 \mathrm{~Hz}\right), 127.64\left(\mathrm{~d}, J_{\mathrm{PC}}=14.5 \mathrm{~Hz}\right), 127.65\left(\mathrm{~d}, J_{\mathrm{PC}}=115.0 \mathrm{~Hz}\right), 145.7$ $\left(J_{\mathrm{PC}}=16.6 \mathrm{~Hz}\right), 148.4\left(J_{\mathrm{PC}}=2.8 \mathrm{~Hz}\right) .{ }^{31} \mathrm{P} \mathrm{NMR}\left(\mathrm{CDCl}_{3}\right): \delta 31.5$. ESI-HRMS Calcd for $\mathrm{C}_{54} \mathrm{H}_{45} \mathrm{Fe}_{4} \mathrm{O}_{6} \mathrm{P}_{2}(\mathrm{M}+1)$ : 1075.0089. Found: 1075.0100 .

The enantiomeric resolution of rac-3 was achieved by chiral HPLC. Among the chiral columns examined, Chiralpak IA showed the most effective separation of the two enantiomers. Under the analysis conditions 
(column length: $250 \mathrm{~mm}$; column i.d.: $4.6 \mathrm{~mm}$; eluent: hexane/2-propanol $=5 / 1$; flow rate: $1.0 \mathrm{~mL} / \mathrm{min}$ ), $(R)-3$ and $(S)-3$ were detected at $17.0 \mathrm{~min}$ and $27.3 \mathrm{~min}$, respectively, and the resolution factor (Rs) for this analysis was 4.6 (see Figure S1). The chiral HPLC resolution of $\mathrm{rac}-\mathbf{3}$ could be conducted on a semi-macro scale as well. Due to the low solubility of the compound, dichloromethane was used as a co-solvent for the semi-macro scale HPLC. A sample of rac-3 (ca. $5 \mathrm{mg}$ in $2 \mathrm{~mL}$ of hexane/2-propanol/dichloromethane = 5/1/1) was resolved cleanly on Chiralpak IA (column length: $250 \mathrm{~mm}$; column i.d.: $20 \mathrm{~mm}$; eluent: hexane/2propanol/dichloromethane $=5 / 1 / 1$; flow rate: $3.0 \mathrm{~mL} / \mathrm{min})$, and $(R)-\mathbf{3}$ and $(S)-\mathbf{3}$ were obtained in enantiomerically pure forms. $[\alpha]^{23}{ }_{\mathrm{D}}=-90\left(c 1.10, \mathrm{CHCl}_{3} ; R\right.$-enantiomer $),[\alpha]^{23} \mathrm{D}=+92\left(c 1.07, \mathrm{CHCl}_{3} ; S\right.$ enantiomer).

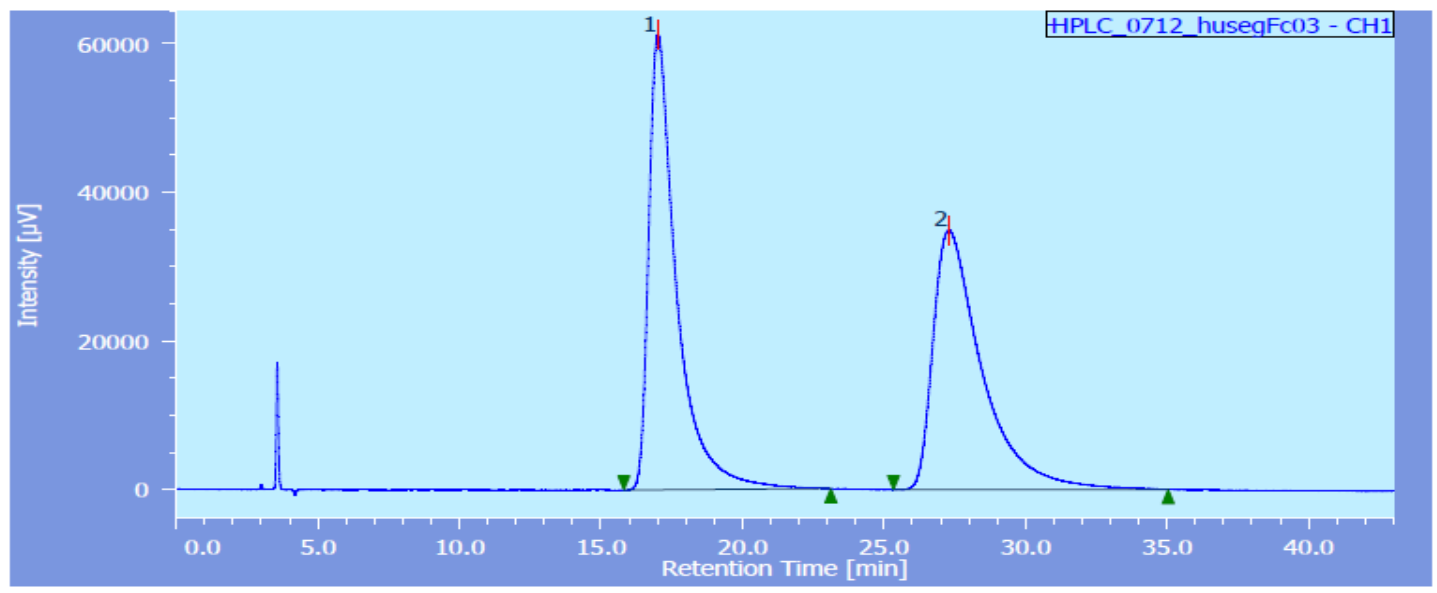

\begin{tabular}{|r|c|c|r|r|r|r|r|r|r|r|}
\hline$\#$ & peak name & CH & tR $[\mathrm{min}]$ & area $[\mu \mathrm{V} \cdot \mathrm{sec}]$ & height $[\mu \mathrm{V}]$ & area $\%$ & height $\%$ & NTP & resolution & symmetry coefficient \\
\hline 1 & $(R)$-isomer & 1 & 17.008 & 4204761 & 61200 & 50.152 & 63.702 & 1842 & 4.609 & 2.107 \\
\hline 2 & $(S)$-isomer & 1 & 27.283 & 4179298 & 34873 & 49.848 & 36.298 & 1430 & $\mathrm{~N} / \mathrm{A}$ & 2.092 \\
\hline
\end{tabular}

Figure S1. Chiral HPLC Analysis of rac-3 on Chiralpak IA (column length: $250 \mathrm{~mm}$; column i.d.: $4.6 \mathrm{~mm}$; eluent: hexane $/ 2$-propanol $=5 / 1$; flow rate: $1.0 \mathrm{~mL} / \mathrm{min}$ ).

$(\boldsymbol{S})$ - or $(\boldsymbol{R})$-Fc-Segphos (1). To a mixture of $(S)$ - or $(R)-3(350 \mathrm{mg}, 326 \mu \mathrm{mol})$ and $\mathrm{NEt}_{3}(0.35 \mathrm{~mL}, 2.3$ mmol) in degassed xylene $(5.0 \mathrm{~mL})$ was added $\mathrm{HSiCl}_{3}(0.16 \mathrm{~mL}, 1.6 \mathrm{mmol})$ under nitrogen at $0{ }^{\circ} \mathrm{C}$. The mixture was stirred at $130{ }^{\circ} \mathrm{C}$ for $15 \mathrm{~h}$. With external cooling with ice-water, the mixture was quenched with a small amount of saturated $\mathrm{NaHCO}_{3}$ (ca. $0.5 \mathrm{~mL}$ ). The resulting suspension was filtered and the solid was washed with hot toluene. The combined organic layer was dried over $\mathrm{MgSO}_{4}$ and evaporated under reduced pressure. The residue was purified by silica gel chromatography (with benzene) to give a yellow solid. Yield: $338 \mathrm{~g}(324 \mu \mathrm{mol} ;>99 \%) .{ }^{1} \mathrm{H}$ NMR $\left(\mathrm{CDCl}_{3}\right): \delta 3.84(\mathrm{br}, 2 \mathrm{H}), 3.87(\mathrm{~s}, 10 \mathrm{H}), 4.11(\mathrm{br}, 2 \mathrm{H}), 4.16(\mathrm{br}, 2 \mathrm{H}), 4.27$ $(\mathrm{br}, 2 \mathrm{H}), 4.38(\mathrm{~s}, 10 \mathrm{H}), 4.39(\mathrm{br}, 2 \mathrm{H}), 4.49(\mathrm{br}, 2 \mathrm{H}), 4.56(\mathrm{br}, 2 \mathrm{H}), 5.27(\mathrm{br}, 2 \mathrm{H}), 6.04(\mathrm{~d}, J=1.2 \mathrm{~Hz}, 2 \mathrm{H}), 6.05$ $(\mathrm{d}, J=1.2 \mathrm{~Hz}, 2 \mathrm{H}), 6.78(\mathrm{~d}, J=8.0 \mathrm{~Hz}, 2 \mathrm{H}), 6.94(\mathrm{~d}, J=8.0 \mathrm{~Hz} 2 \mathrm{H}) .{ }^{13} \mathrm{C} \mathrm{NMR}\left(\mathrm{CDCl}_{3}\right): \delta 68.7,69.0,69.1$, $69.4,69.5,70.6,70.99,71.04,71.8$ (pseudo-t, $J_{\mathrm{PC}}=9.8 \mathrm{~Hz}$ ), 75.3 (pseudo-t, $J_{\mathrm{PC}}=20.6 \mathrm{~Hz}$ ), 79.5, 81.5 (pseudo$\mathrm{t}, J_{\mathrm{PC}}=7.3 \mathrm{~Hz}$ ), 100.9, 108.6, 121.4 (pseudo-t, $J_{\mathrm{PC}}=20.1 \mathrm{~Hz}$ ), 129.0, 133.0 (pseudo-t, $J_{\mathrm{PC}}=6.4 \mathrm{~Hz}$ ), 146.0 (pseudo-t, $\left.J_{\mathrm{PC}}=5.9 \mathrm{~Hz}\right), 147.7 .{ }^{31} \mathrm{P}$ NMR $\left(\mathrm{CDCl}_{3}\right)$ : -38.4. ESI-HRMS Calcd for $\mathrm{C}_{54} \mathrm{H}_{45} \mathrm{Fe}_{4} \mathrm{O}_{4} \mathrm{P}_{2}(\mathrm{M}+1)$ : 1043.0191. Found: 1043.0206. $[\alpha]^{22} \mathrm{D}=+107\left(c 1.71, \mathrm{CHCl}_{3} ; R\right.$-enantiomer $),[\alpha]^{22} \mathrm{D}=-86\left(c 1.70, \mathrm{CHCl}_{3} ; S\right.$ enantiomer).

rac-(Fc-Segphos)PdCl 2 (rac-4). A mixture of $\mathrm{PdCl}_{2}(\mathrm{cod})(5.7 \mathrm{mg}, 20 \mu \mathrm{mol})$ and $\mathrm{rac}-4(21 \mathrm{mg}, 20 \mathrm{mmol})$ was dissolved in $\mathrm{CDCl}_{3}(2.0 \mathrm{~mL})$ and the reaction was monitored by the ${ }^{1} \mathrm{H}-$ and ${ }^{31} \mathrm{P}-\mathrm{NMR}$ measurements. In several hours, the color of the solution turned from deep-red to pale orange with the precipitation of deep-red prismatic crystals. ${ }^{1} \mathrm{H}$ NMR $\left(\mathrm{CDCl}_{3}\right)$ : $\delta 3.61(\mathrm{br}, 2 \mathrm{H}), 3.96(\mathrm{br}, 2 \mathrm{H}), 3.97(\mathrm{~s}, 10 \mathrm{H}), 4.04-4.05(\mathrm{~m}, 2 \mathrm{H}), 4.36(\mathrm{br}$, 2H), $4.52(\mathrm{~s}, 10 \mathrm{H}), 4.56(\mathrm{br}, 2 \mathrm{H}), 4.61$ (br, 2H), $4.72(\mathrm{br}, 2 \mathrm{H}), 5.68(\mathrm{~d}, J=1.2 \mathrm{~Hz}, 2 \mathrm{H}), 5.81$ (d, $J=1.2 \mathrm{~Hz}$, $2 \mathrm{H}), 6.06(\mathrm{br}, 2 \mathrm{H}), 6.71(\mathrm{dd}, J=8.4$ and $1.2 \mathrm{~Hz}, 2 \mathrm{H}), 9.40(\mathrm{dd}, J=12.8$ and $8.4 \mathrm{~Hz} 2 \mathrm{H}) .{ }^{31} \mathrm{P} \mathrm{NMR}\left(\mathrm{CDCl}_{3}\right): \delta$ 11.6. The ${ }^{13} \mathrm{C}$ NMR spectrum of this compound could not be recorded due to the low solubility in chloroform.

The single-crystals of rac-4 were grown as deep-red prisms by recrystallization from chloroform/dichloromethane/pentane, and the ball-and stick drawing of the X-ray structure is shown in Figure 
2 in the main text. The space-filling drawings of the X-ray structure (left: front view, right: side view) are shown below for the better representation of the steric bulk of the ferrocenyl substituents in rac-4.
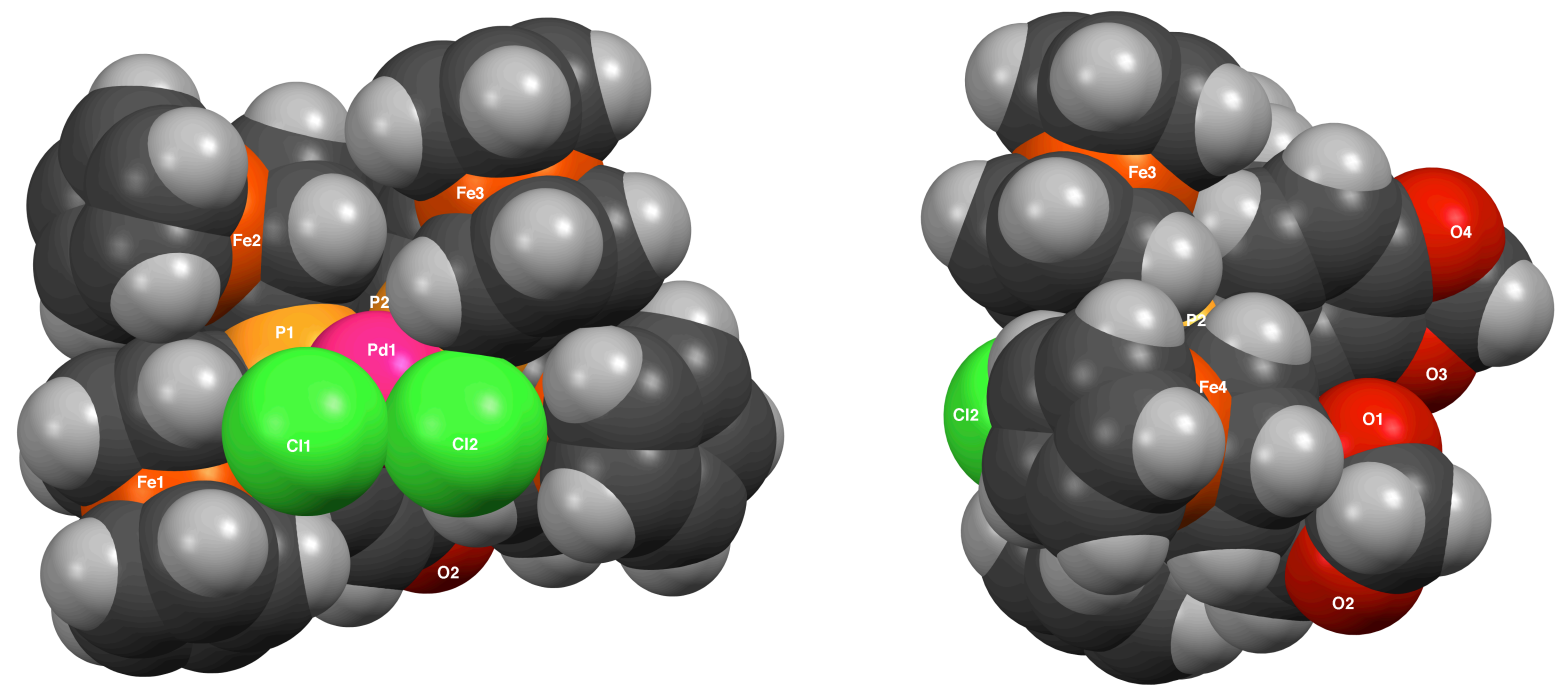

Figure S2. Space-filling drawings of the X-ray structure of $\mathrm{rac}-\mathbf{4}$ with selected atom numbering (left: front view, right: side view).

General Procedure for Palladium-Catalyzed Asymmetric Synthesis of Axially Chiral Allenes. The reaction was carried out according to the reported procedure. ${ }^{8-10}$ The reaction conditions and the results are summarized in Table 1. A mixture of $\mathrm{Pd}(\mathrm{dba})_{2}(4.3 \mathrm{mg}, 7.5 \mu \mathrm{mol})$, chiral bisphosphine $(82 \mu \mathrm{mol})$, and 2bromo-1,3-butadiene $5(0.15 \mathrm{mmol})$ was dissolved in THF $(1.5 \mathrm{~mL})$, and the solution was added to a mixture of pronucleophile $6(0.25 \mathrm{mmol})$ and an appropriate base $(0.25 \mathrm{mmol})$ in THF $(1 \mathrm{~mL})$. The mixture was stirred at $40{ }^{\circ} \mathrm{C}$ for $12 \mathrm{~h}$, then filtered through a short pad of $\mathrm{Al}_{2} \mathrm{O}_{3}$ to remove the precipitated inorganic salts. The alumina pad was washed with small amount of $\mathrm{Et}_{2} \mathrm{O}$ three times and the combined solution was evaporated to dryness under reduced pressure. The orange-yellow residue was chromatographed on $\mathrm{Al}_{2} \mathrm{O}_{3}$ to give allene $\mathbf{7}$ in pure form. The characterization data of allenic products 7 as well as the conditions for the chiral HPLC analysis are listed below.

(R)-Diethyl 2-Phenyl-2-(4-phenylbuta-2,3-dienyl)propane-1,3-dioate (7aw). ${ }^{1} \mathrm{H}$ NMR $\left(\mathrm{CDCl}_{3}\right): \delta 1.20$ $126(\mathrm{~m}, 6 \mathrm{H}), 3.15-3.17(\mathrm{~m}, 2 \mathrm{H}), 4.18-4.29(\mathrm{~m}, 4 \mathrm{H}), 5.42(\mathrm{dt}, J=7.8$ and $7.2 \mathrm{~Hz}, 1 \mathrm{H}), 6.02-6.05(\mathrm{~m}, 1 \mathrm{H}), 7.10-$ $7.17(\mathrm{~m}, 3 \mathrm{H}), 7.21-7.24(\mathrm{~m}, 2 \mathrm{H}), 7.30-7.37(\mathrm{~m}, 3 \mathrm{H}), 7.44-7.47(\mathrm{~m}, 2 \mathrm{H}) .{ }^{13} \mathrm{C}$ NMR $\left(\mathrm{CDCl}_{3}\right): \delta 13.96,13.99$, 36.0, 61.75, 61.77, 62.8, 89.9, 94.5, 126.9 (2C), 127.6, 128.22, 128.24, 128.5, 134.2, 136.5, 170.1, 170.2, 206.9. ESI-HRMS Calcd for $\mathrm{C}_{23} \mathrm{H}_{25} \mathrm{O}_{4}(\mathrm{M}+1): 365.1753$. Found: 365.1759 . Chiral HPLC Analysis Conditions: Chiralpak AS-H; eluent: hexane $/ \mathrm{PrOH}=500 / 1$; flow rate: $0.5 \mathrm{~mL} / \mathrm{min} .[\alpha]^{31} \mathrm{D}=-148\left(c 0.47, \mathrm{CHCl}_{3}\right.$; for the sample of $86 \%$ ee).

$(\boldsymbol{R})$-Dimethyl 2-[4-(4-Methoxyphenyl)buta-2,3-dienyl]-2-methylpropane-1,3-dioate (7bx). ${ }^{1} \mathrm{H}$ NMR $\left(\mathrm{CDCl}_{3}\right): \delta 1.51(\mathrm{~s}, 3 \mathrm{H}), 2.68-2.70(\mathrm{~m}, 2 \mathrm{H}), 3.70(\mathrm{~s}, 3 \mathrm{H}), 3.72(\mathrm{~s}, 3 \mathrm{H}), 3.80(\mathrm{~s}, 3 \mathrm{H}), 5.42(\mathrm{td}, J=8.0$ and $6.4 \mathrm{~Hz}$, $1 \mathrm{H}), 6.10(\mathrm{dt}, J=6.4$ and $2.4 \mathrm{~Hz}, 1 \mathrm{H}), 6.83-6.85(\mathrm{~m}, 2 \mathrm{H}), 7.17-7.19(\mathrm{~m}, 2 \mathrm{H}) .{ }^{13} \mathrm{C} \mathrm{NMR}\left(\mathrm{CDCl}_{3}\right): \delta 19.9,35.7$, 52.56, 52.60, 53.8, 55.2, 89.2, 94.0, 114.1, 126.3, 127.9, 158.7, 172.1, 172.2, 206.3. ESI-HRMS Calcd for $\mathrm{C}_{17} \mathrm{H}_{21} \mathrm{O}_{5}(\mathrm{M}+1)$ : 305.1389 Found: 305.1391. Chiral HPLC Analysis Conditions: Chiralpak AD-H; eluent: hexane $/ \mathrm{PrOH}=20 / 1$; flow rate: $0.8 \mathrm{~mL} / \mathrm{min} .[\alpha]^{22} \mathrm{D}=-47\left(\right.$ c $2.20, \mathrm{CHCl}_{3}$; for the sample of $84 \%$ ee $)$.

(R)-Dimethyl 2-(Dodeca-2,3-dienyl)-2-methylpropane-1,3-dioate (7cx). ${ }^{1} \mathrm{H}$ NMR $\left(\mathrm{CDCl}_{3}\right): \delta 0.88(\mathrm{t}, J=$ $6.8 \mathrm{~Hz}, 3 \mathrm{H}), 1.26-1.41(\mathrm{~m}, 12 \mathrm{H}), 1.44(\mathrm{~s}, 3 \mathrm{H}), 1.92-2.01(\mathrm{~m}, 2 \mathrm{H}), 2.51-2.62(\mathrm{~m}, 2 \mathrm{H}), 3.72(\mathrm{~s}, 6 \mathrm{H}), 4.91-4.96$ $(\mathrm{m}, 1 \mathrm{H}), 5.05-5.10(\mathrm{~m}, 1 \mathrm{H}) .{ }^{13} \mathrm{C}$ NMR $\left(\mathrm{CDCl}_{3}\right): \delta 14.1,19.7,22.7,28.8,29.1,29.2,29.3,29.4,31.9,36.0$, 52.48, 52.51, 53.9, 85.0, 91.0, 172.28, 172.33, 205.9. ESI-HRMS Calcd for $\mathrm{C}_{18} \mathrm{H}_{30} \mathrm{O}_{4} \mathrm{Na}(\mathrm{M}+\mathrm{Na}): 333.2042$. Found: 333.2049. Chiral HPLC Analysis Conditions: Chiralpak IB; eluent: hexane $/{ }^{2} \mathrm{PrOH}=600 / 1$; flow rate: $0.25 \mathrm{~mL} / \mathrm{min} .[\alpha]^{20} \mathrm{D}=-35\left(c 1.00, \mathrm{CHCl}_{3}\right.$; for the sample of $74 \%$ ee $)$. 
(R)-Diethyl 2-(5,5-Dimethyl-2,3-hexadienyl)-2-acetylaminopropane-1,3-dioate (7dy). This is a known compound and its ${ }^{1} \mathrm{H}-\mathrm{NMR}$ data are consistent with those reported previously. ${ }^{9}$ Chiral HPLC Analysis Conditions: Chiralpak IA; eluent: hexane/ ${ }^{2} \mathrm{PrOH}=20 / 1$; flow rate: $0.5 \mathrm{~mL} / \mathrm{min}$. $[\alpha]^{22}{ }_{\mathrm{D}}=-39\left(c 0.60, \mathrm{CHCl}_{3}\right.$; for the sample of $92 \%$ ee).

(R)-2-[4-(Trimethylsilyl)buta-2,3-dienyl]benzodithiole 1,1,3,3-Tetraoxide (7ez). ${ }^{1} \mathrm{H}$ NMR $\left(\mathrm{CDCl}_{3}\right)$ : $\delta$ $0.15(\mathrm{~s}, 9 \mathrm{H}), 2.97-3.01(\mathrm{~m}, 2 \mathrm{H}), 4.44(\mathrm{t}, J=7.1 \mathrm{~Hz}, 1 \mathrm{H}), 5.00(\mathrm{q}, J=6.9 \mathrm{~Hz}, 1 \mathrm{H}), 5.19(\mathrm{dt}, J=6.9 \mathrm{and} 3.4 \mathrm{~Hz}$, $1 \mathrm{H}), 7.91-7.93(\mathrm{~m}, 2 \mathrm{H}), 8.02-8.04(\mathrm{~m}, 2 \mathrm{H}) .{ }^{13} \mathrm{C} \mathrm{NMR}(\mathrm{CDCl} 3): \delta-1.00,22.2,73.7,76.2,86.0,122.6(2 \mathrm{C})$, 135.1 (2C), 137.65, 137.72, 209.5. ESI-HRMS Calcd for $\mathrm{C}_{14} \mathrm{H}_{18} \mathrm{O}_{4} \mathrm{~S}_{2} \mathrm{SiNa}(\mathrm{M}+\mathrm{Na}): 365.0313$ Found: 365.0312 . Chiral HPLC Analysis Conditions: Chiralpak IB; eluent: hexane $/{ }^{2} \operatorname{PrOH}=20 / 1$; flow rate: $1.0 \mathrm{ml} / \mathrm{min} .[\alpha]^{20} \mathrm{D}=$ -101 ( c $1.00, \mathrm{CHCl}_{3}$; for the sample of $87 \%$ ee).

\section{References.}

(1) Bildstein, B.; Malaun, M.; Kopacka, H.; Wurst, K.; Mitterböck, M.; Ongania, K-H.; Opromolla, G.; Zanello, P. $N, N^{\prime}$-Diferrocenyl- $N$-heterocyclic Carbenes and Their Derivatives. Organometallics 1999, $18,4325-4336$.

(2) Drew, D.; Doyle, J. R. Cyclic-Diolefin Complexes of Platinum and Palladium. Inorg. Synth. 1972, 13, 47-55.

(3) Ukai, T.; Kawazura, H.; Ishii, Y.; Bonnet, J. J.; Ibers, J. A. Chemistry of DibenzylideneacetonePalladium(0) complexes: I. Novel Tris(dibenzylideneacetone)dipalladium(solvent) Complexes and Their Reactions with Quinones. J. Organomet. Chem. 1974, 65, 253-266.

(4) Saito, T.; Yokozawa, T.; Ishizaki, T.; Moroi, T.; Sayo, N.; Miura, T.; Kumobayashi, H. New Chiral Diphosphine Ligands Designed to Have a Narrow Dihedral Angle in the Biaryl Backbone. Adv. Synth. Catal. 2001, 343, 264-267.

(5) Ogasawara, M.; Ikeda, H.; Hayashi, T. $\pi$-Allylpalladium-Mediated Catalytic Synthesis of Functionalized Allenes. Angew. Chem., Int. Ed. 2000, 39, 1042-1044.

(6) Ogasawara, M.; Murakami, H.; Furukawa, T.; Takahashi, T.; Shibata, N. Synthesis of Fluorinated Allenes via Palladium-Catalyzed Monofluoromethylation Using FBSM. Chem. Commun. 2009, 73667368.

(7) Ogasawara, M.; Nagano, T.; Hayashi, T. A New Route to Methyl (R,E)-(-)-Tetradeca-2,4,5-trienoate (Pheromone of Acanthoscelides obtectus) Utilizing a Palladium-Catalyzed Asymmetric Allene Formation Reaction. J. Org. Chem. 2005, 70, 5764-5767.

(8) Ogasawara, M.; Ikeda, H.; Nagano, T.; Hayashi, T. Palladium-Catalyzed Asymmetric Synthesis of Axially Chiral Allenes: A Synergistic Effect of Dibenzalacetone on High Enantioselectivity. J. Am. Chem. Soc. 2001, 123, 2089-2090.

(9) Ogasawara, M.; Okada, A.; Subbarayan, V.; Sörgel, S.; Takahashi, T. Palladium-Catalyzed Asymmetric Synthesis of Axially Chiral Allenylsilanes and Their Application to $\mathrm{S}_{\mathrm{E}} 2^{\prime}$ Chirality Transfer Reactions. Org. Lett. 2010, 12, 5736-5739.

(10) Baxter, S. G.; Collins, R. L.; Cowley, A. H.; Sena, S. F. Ferrocenyl-Substituted Phosphenium Cations and Phosphide Anions. Inorg. Chem. 1983, 22, 3475-3479. 


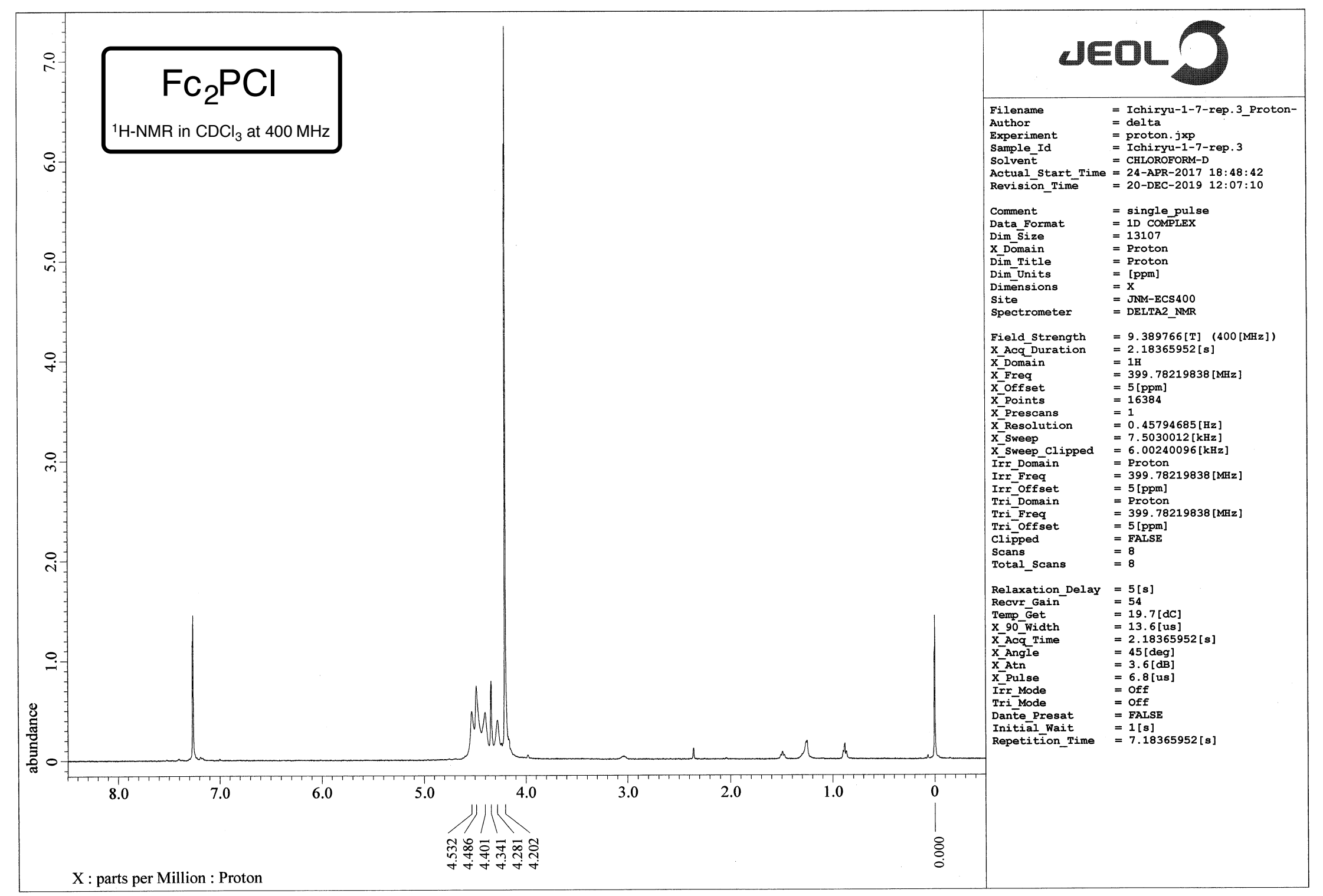

Figure S3. ${ }^{1} \mathrm{H}-\mathrm{NMR}$ Spectrum of $\mathrm{Fc}_{2} \mathrm{PCl}$ in $\mathrm{CDCl}_{3}$ at $400 \mathrm{MHz}$. 


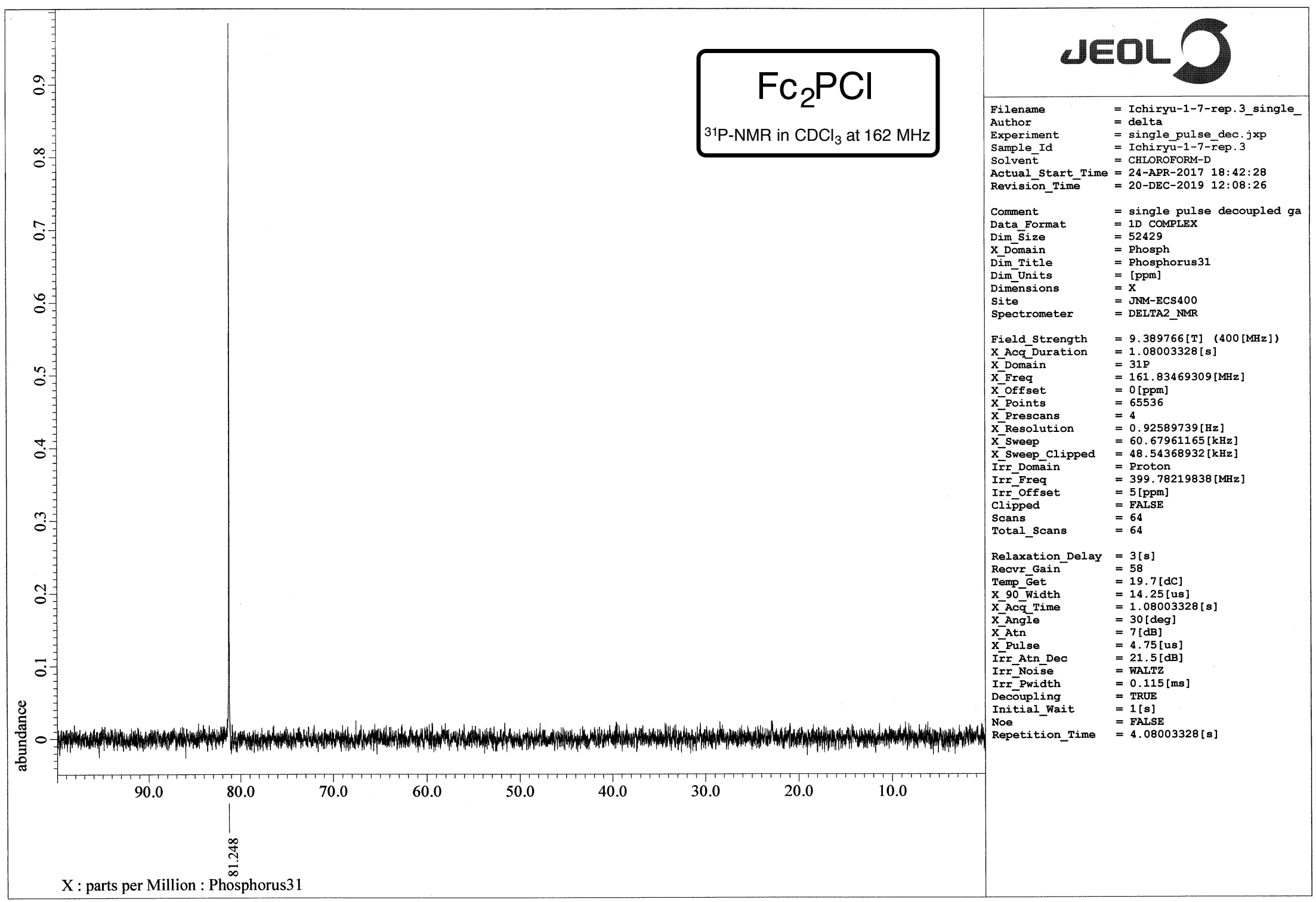

Figure S4. ${ }^{31} \mathrm{P}-\mathrm{NMR}$ Spectrum of $\mathrm{Fc}_{2} \mathrm{PCl}$ in $\mathrm{CDCl}_{3}$ at $162 \mathrm{MHz}$. 


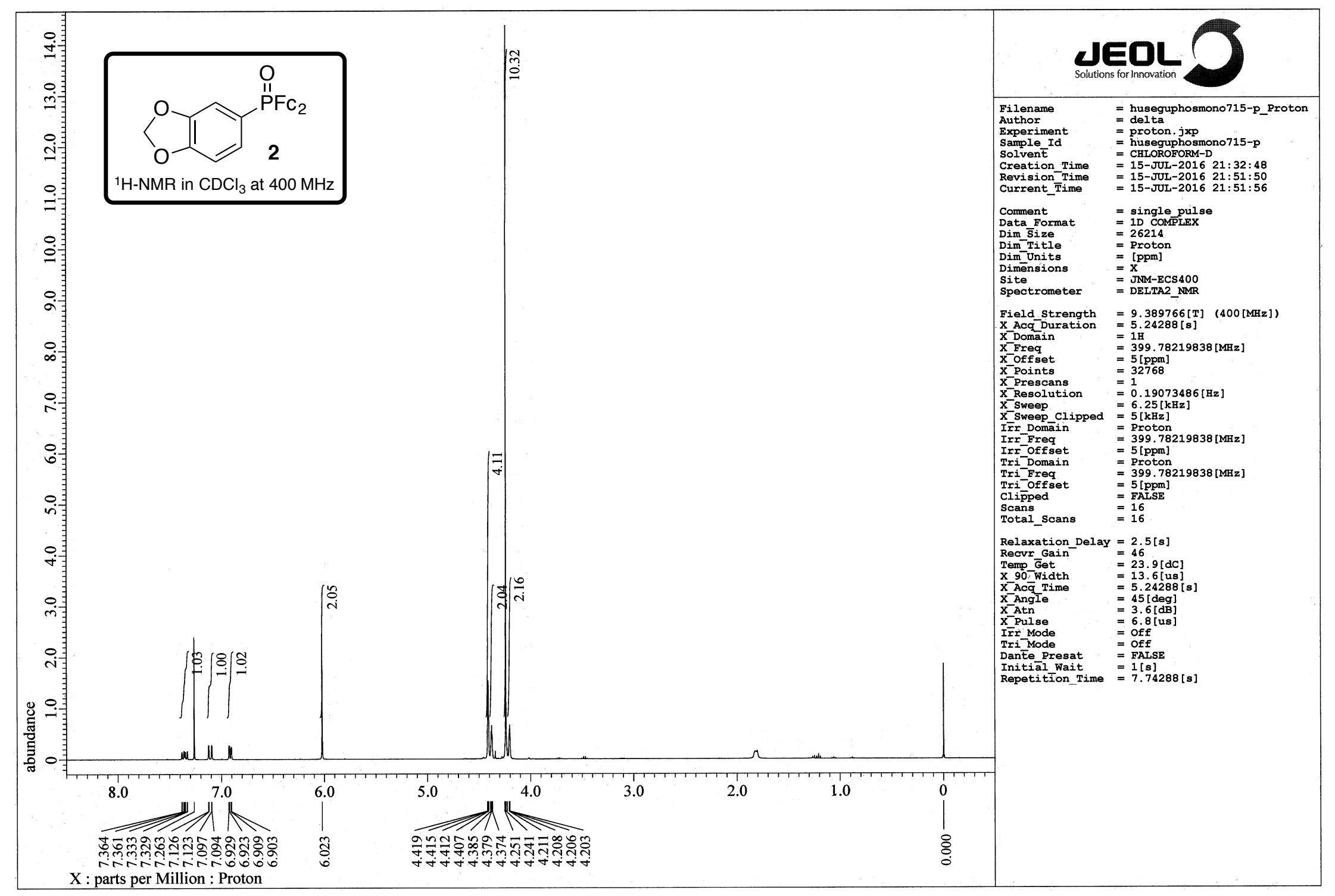

Figure S5. ${ }^{1} \mathrm{H}-\mathrm{NMR}$ Spectrum of 2 in $\mathrm{CDCl}_{3}$ at $400 \mathrm{MHz}$. 


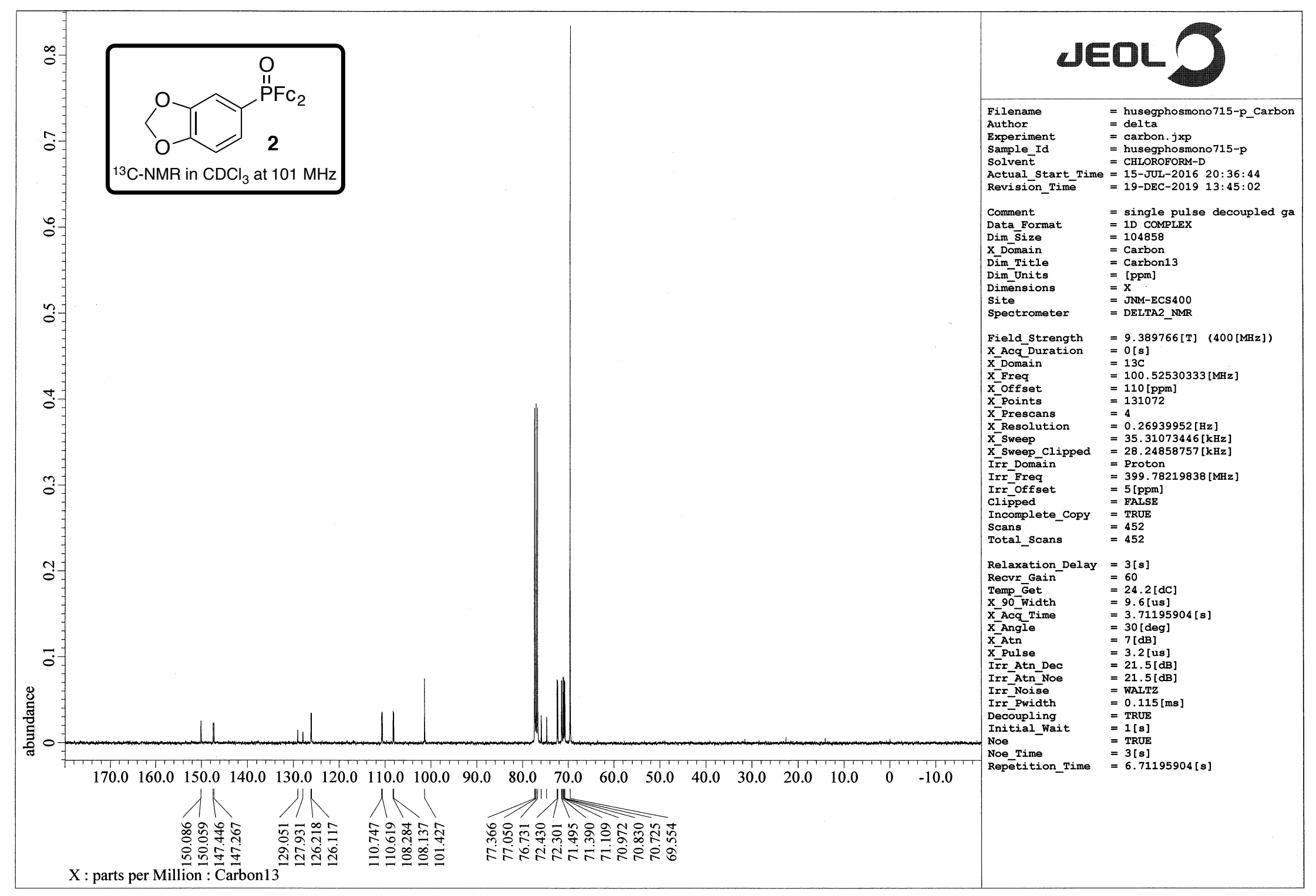

Figure S6. ${ }^{13} \mathrm{C}-\mathrm{NMR}$ Spectrum of 2 in $\mathrm{CDCl}_{3}$ at $101 \mathrm{MHz}$. 


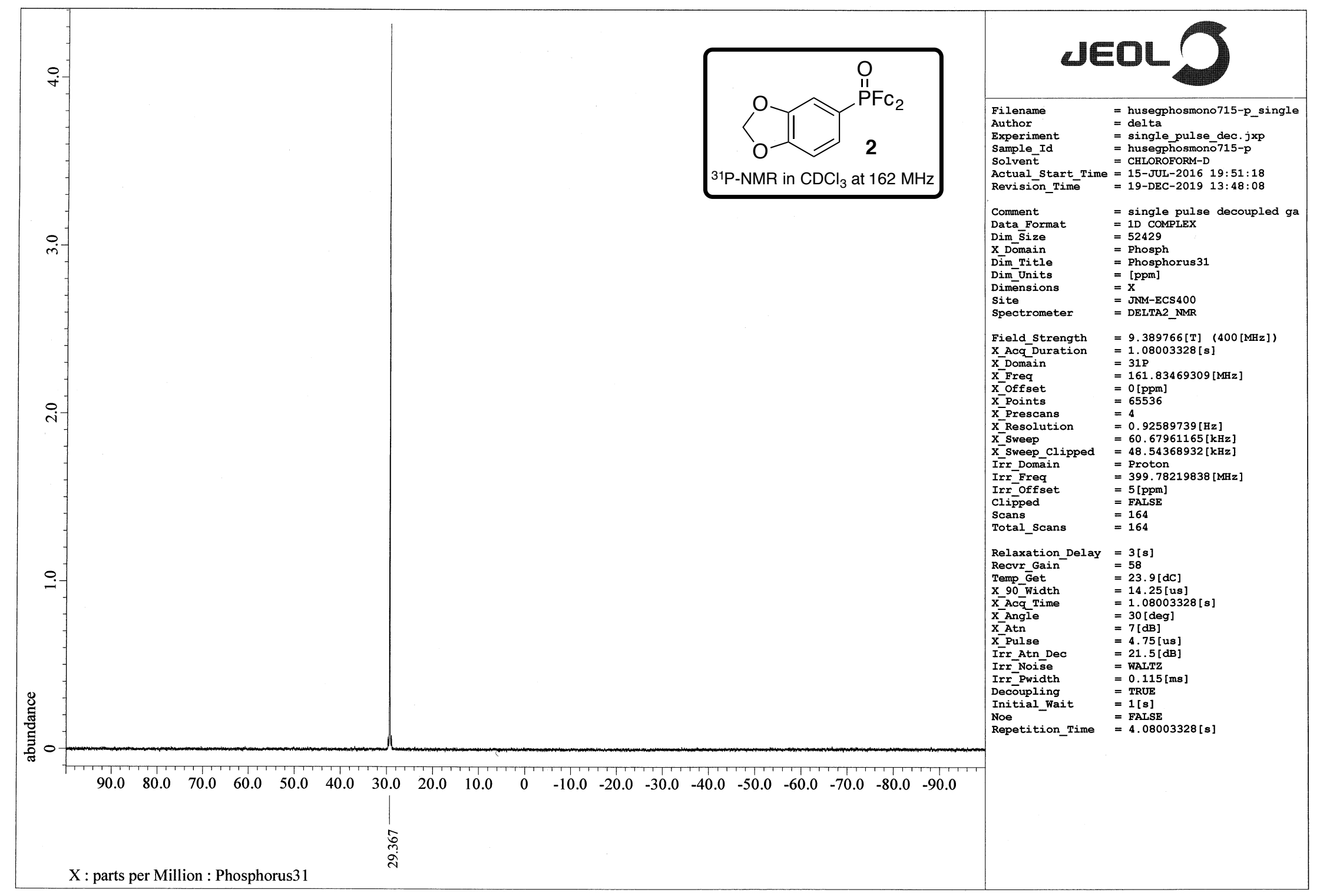

Figure S7. ${ }^{31} \mathrm{P}-\mathrm{NMR}$ Spectrum of 2 in $\mathrm{CDCl}_{3}$ at $162 \mathrm{MHz}$. 


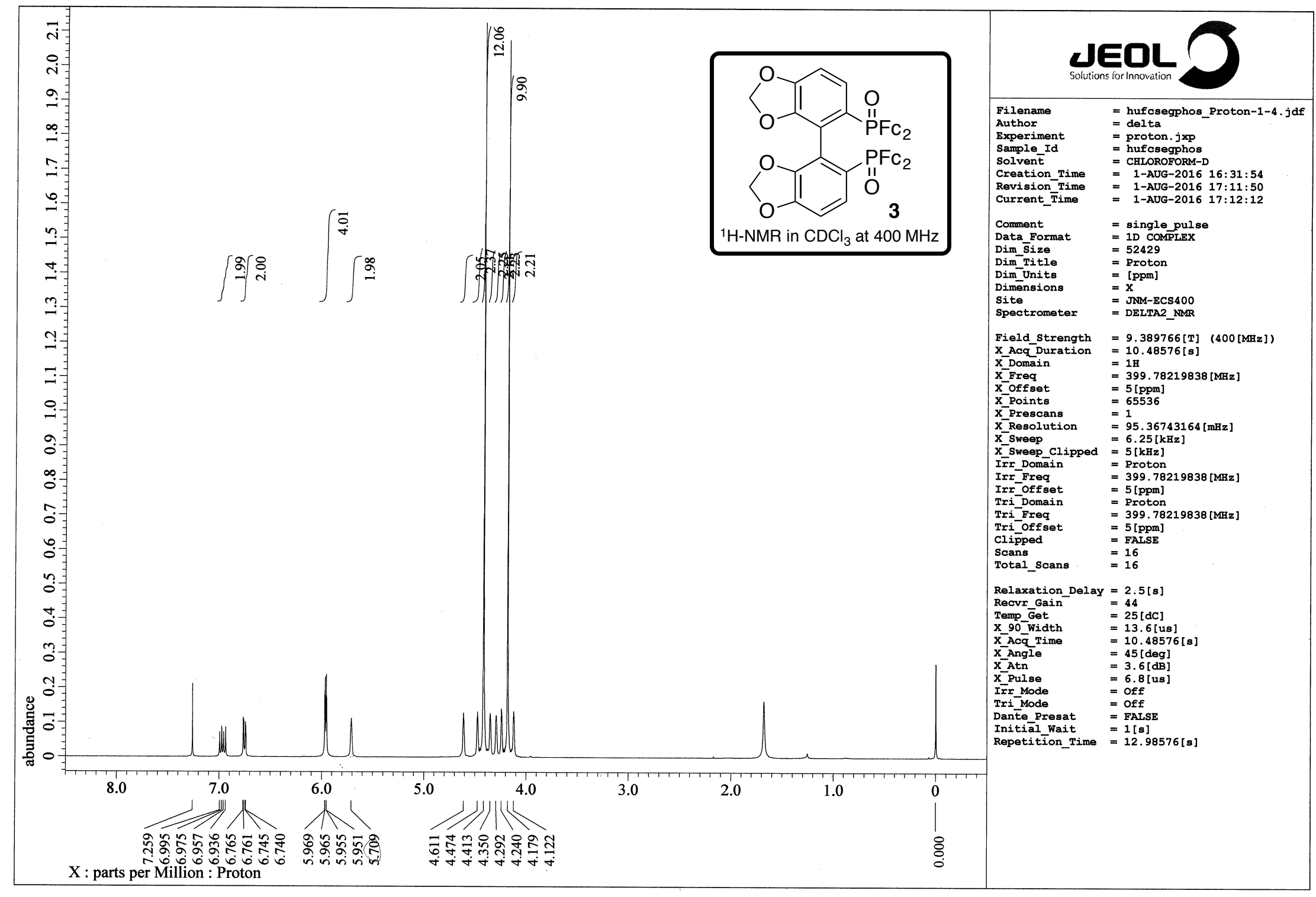

Figure S8. ${ }^{1} \mathrm{H}-\mathrm{NMR}$ Spectrum of 3 in $\mathrm{CDCl}_{3}$ at $400 \mathrm{MHz}$. 


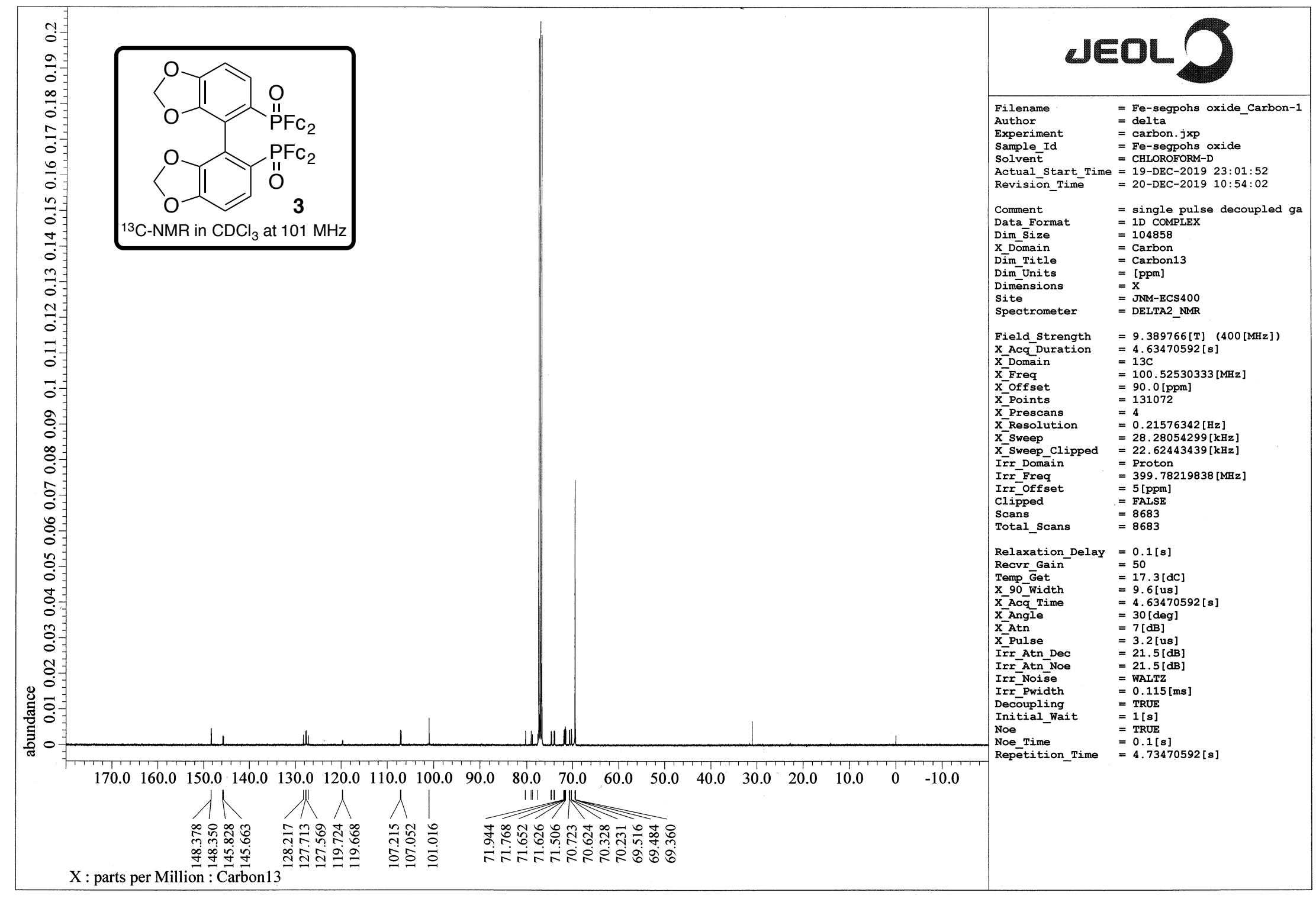

Figure S9. ${ }^{13} \mathrm{C}$-NMR Spectrum of $\mathbf{3}$ in $\mathrm{CDCl}_{3}$ at $101 \mathrm{MHz}$. 


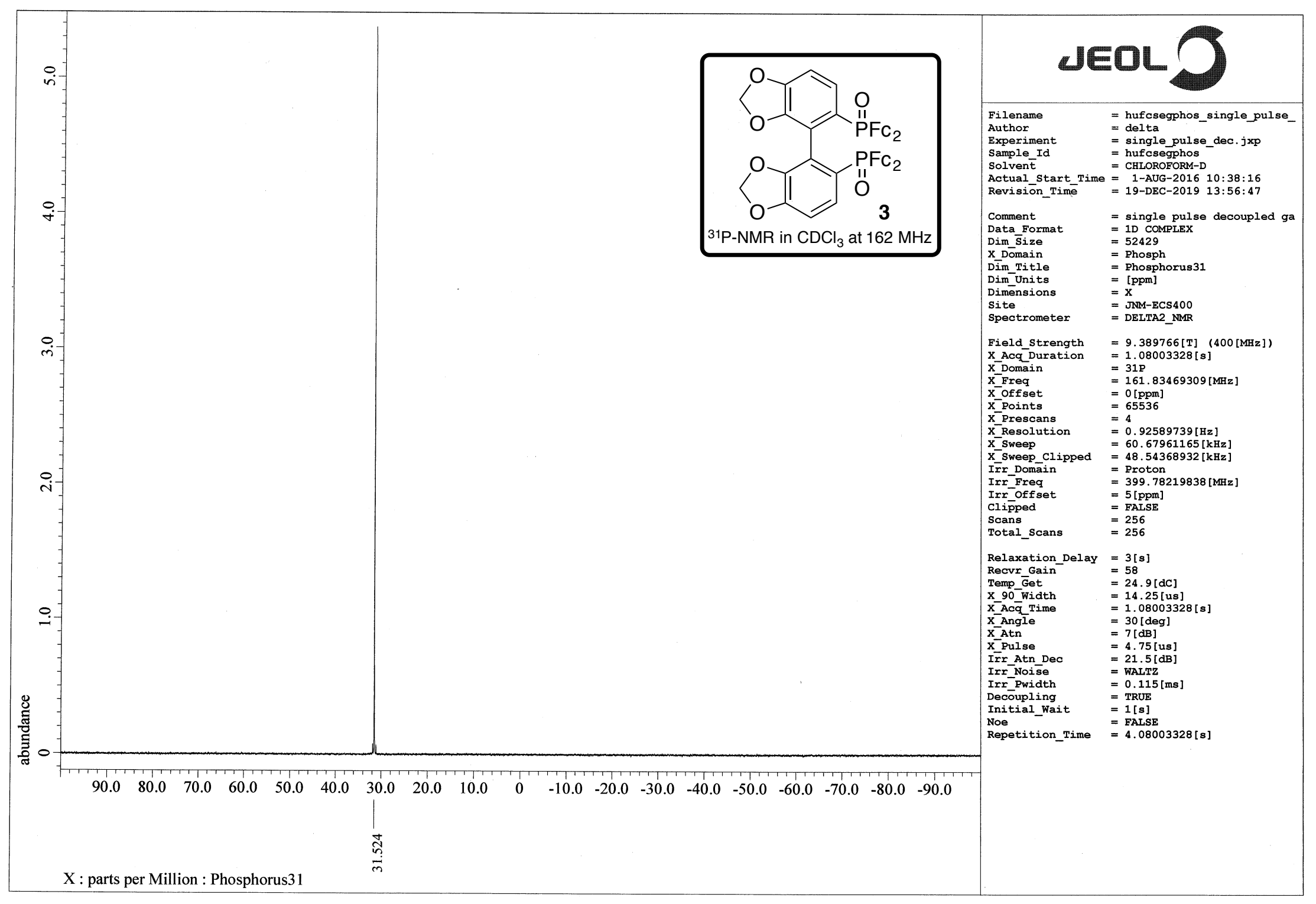

Figure S10. ${ }^{31} \mathrm{P}-\mathrm{NMR}$ Spectrum of $\mathbf{3}$ in $\mathrm{CDCl}_{3}$ at $162 \mathrm{MHz}$. 


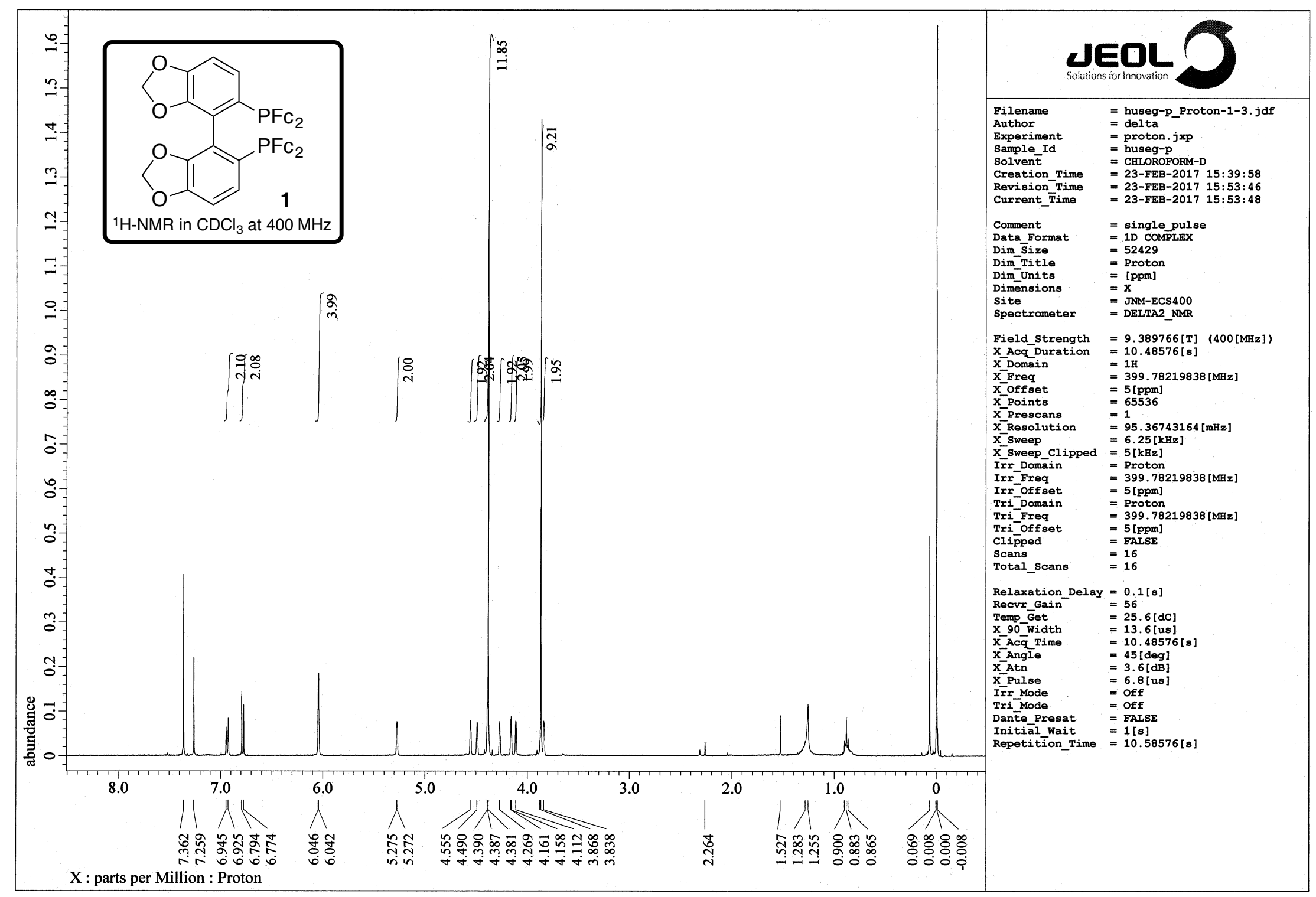

Figure S11. ${ }^{1} \mathrm{H}-\mathrm{NMR}$ Spectrum of 1 in $\mathrm{CDCl}_{3}$ at $400 \mathrm{MHz}$. 


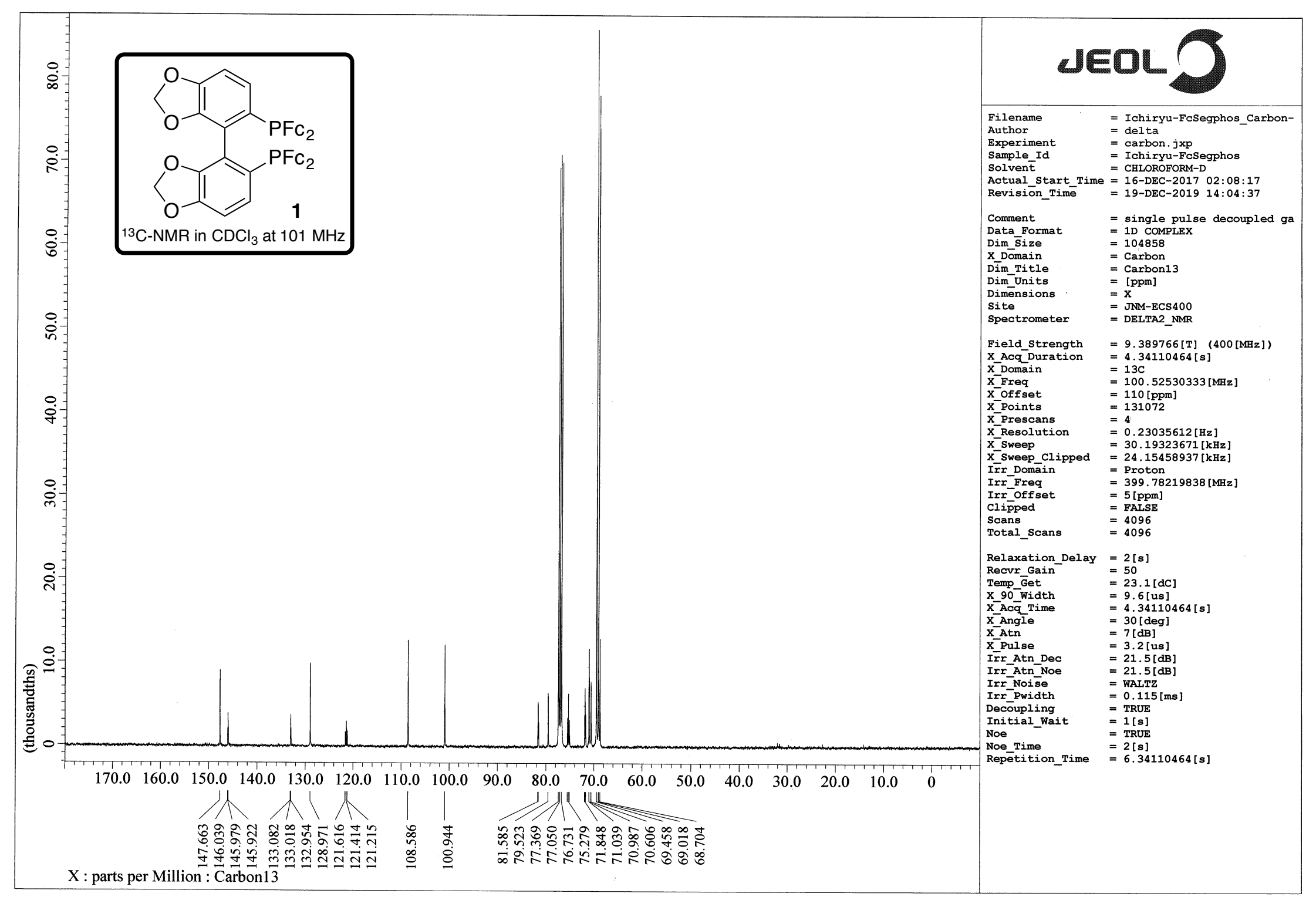

Figure S12. ${ }^{13} \mathrm{C}-\mathrm{NMR}$ Spectrum of $\mathbf{1}$ in $\mathrm{CDCl}_{3}$ at $101 \mathrm{MHz}$. 


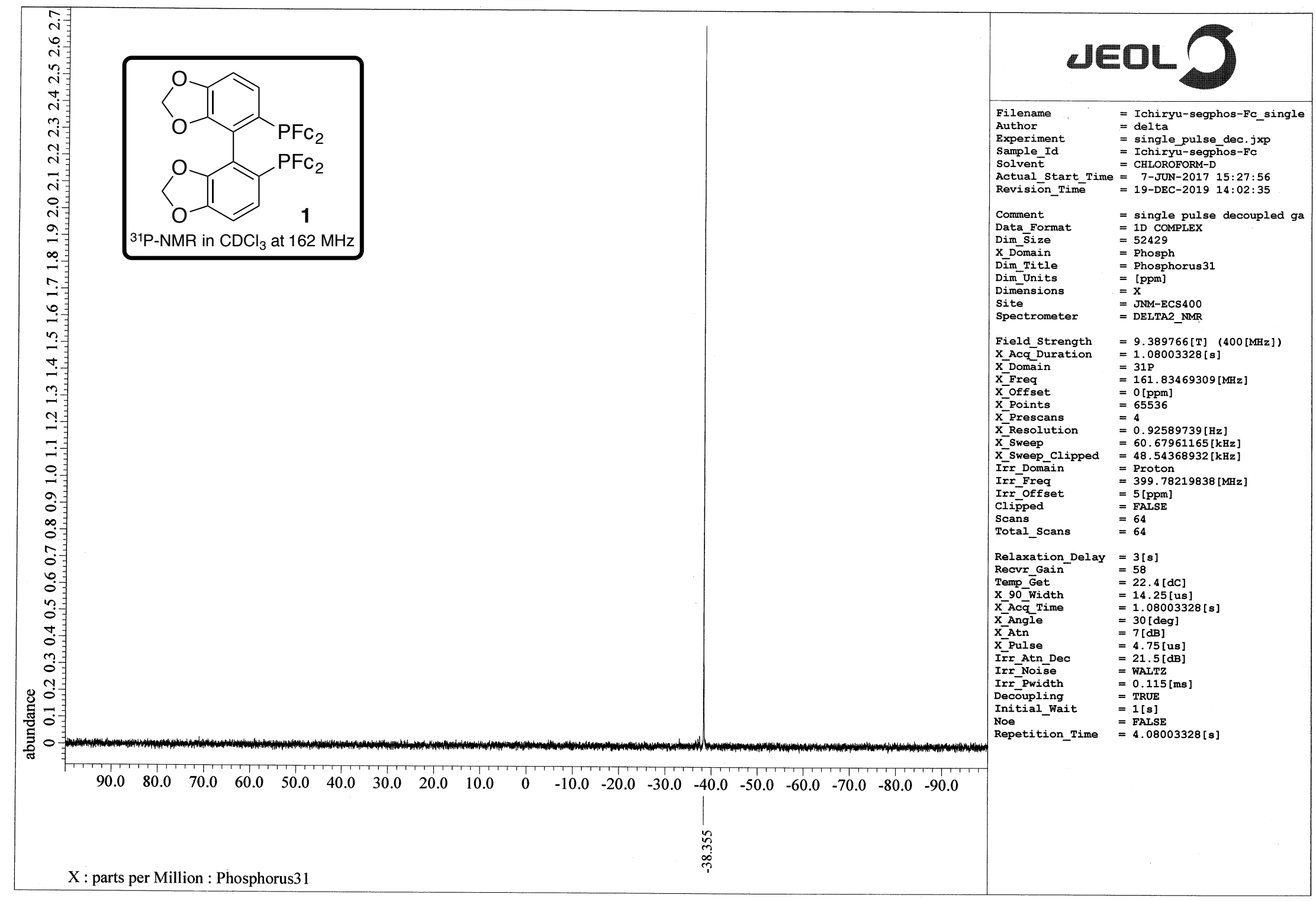

Figure S13. ${ }^{31} \mathrm{P}-\mathrm{NMR}$ Spectrum of 1 in $\mathrm{CDCl}_{3}$ at $162 \mathrm{MHz}$. 


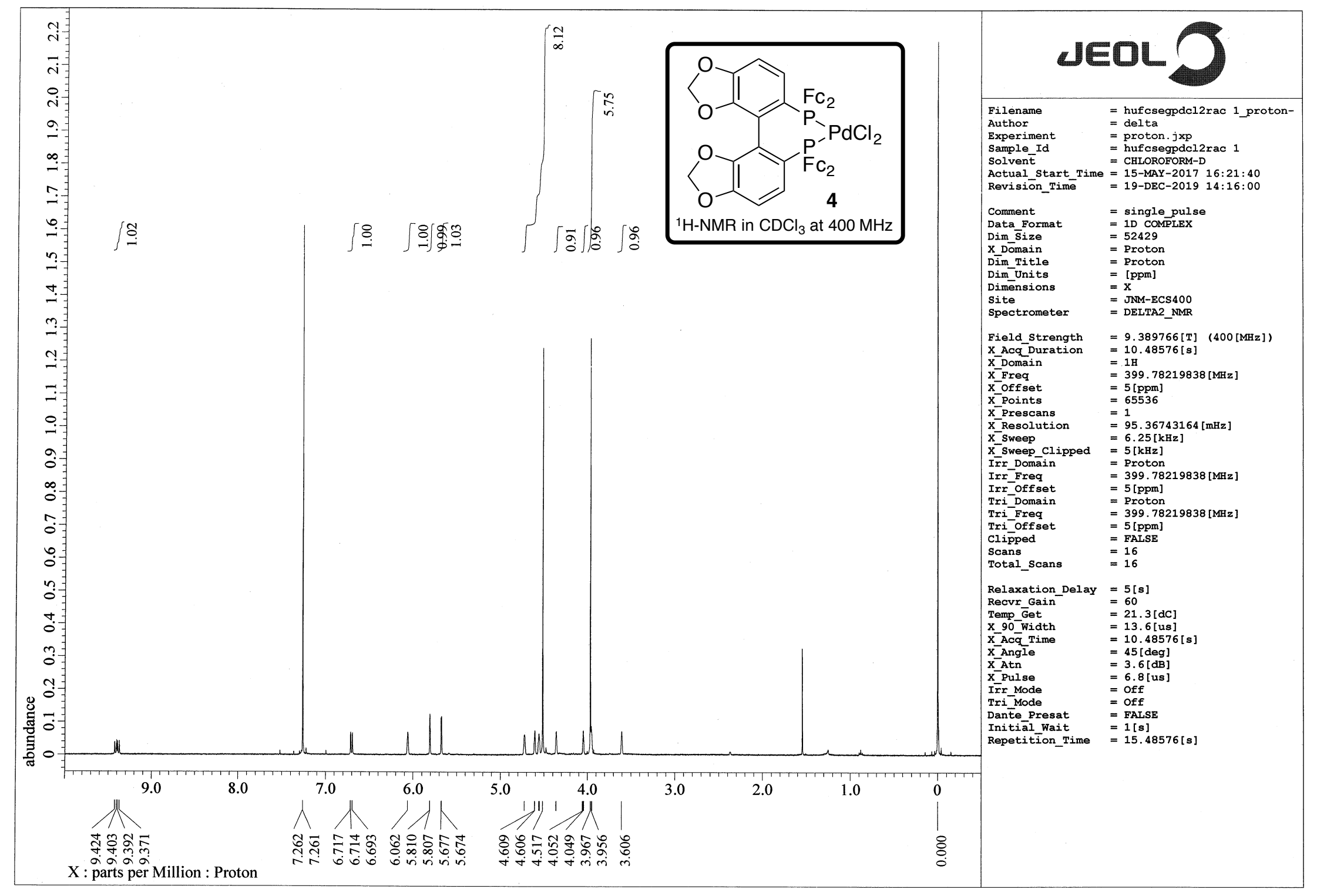

Figure S14. ${ }^{1} \mathrm{H}-\mathrm{NMR}$ Spectrum of 4 in $\mathrm{CDCl}_{3}$ at $400 \mathrm{MHz}$. 


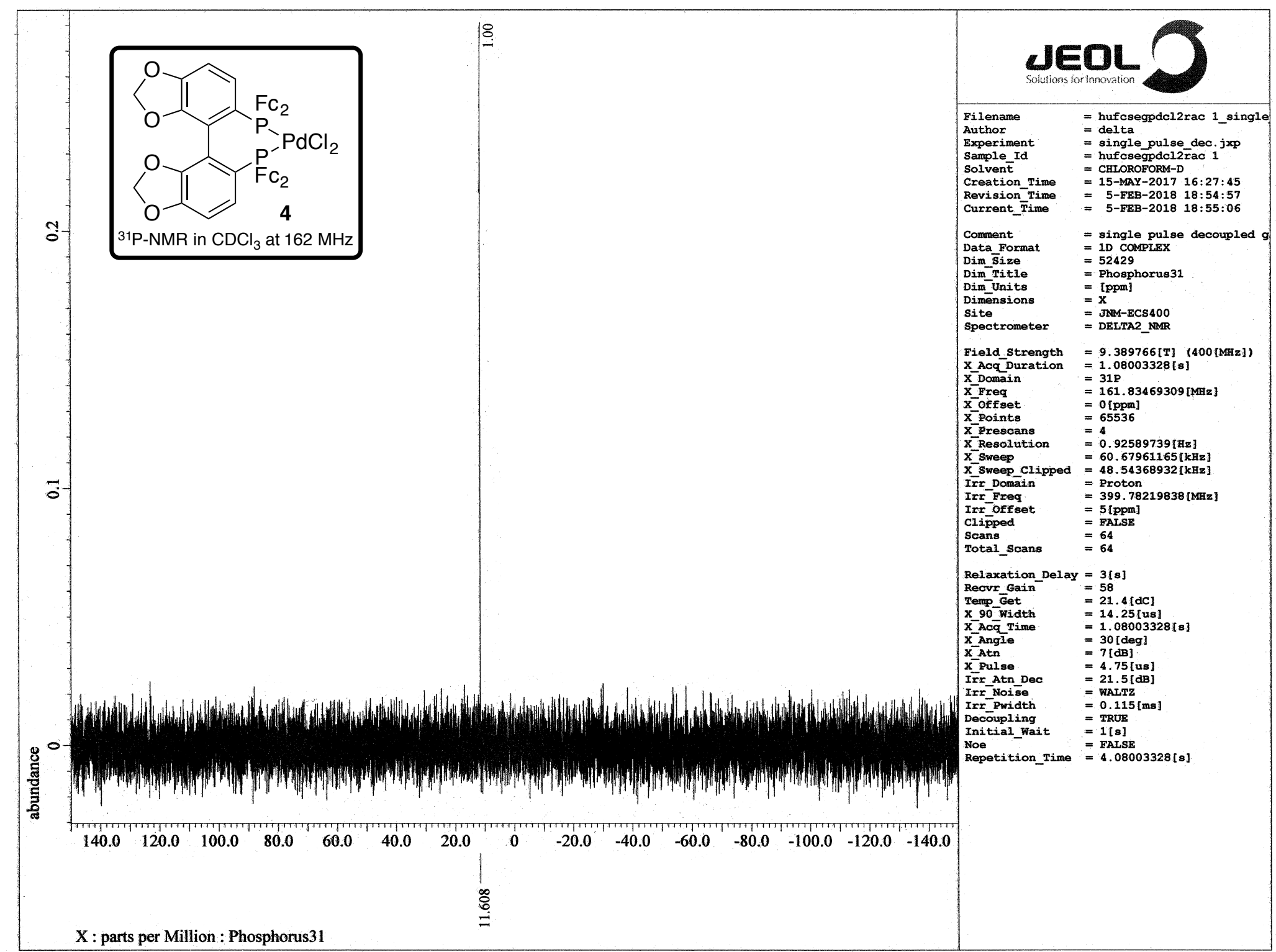

Figure S15. ${ }^{31} \mathrm{P}-\mathrm{NMR}$ Spectrum of 4 in $\mathrm{CDCl}_{3}$ at $162 \mathrm{MHz}$. 


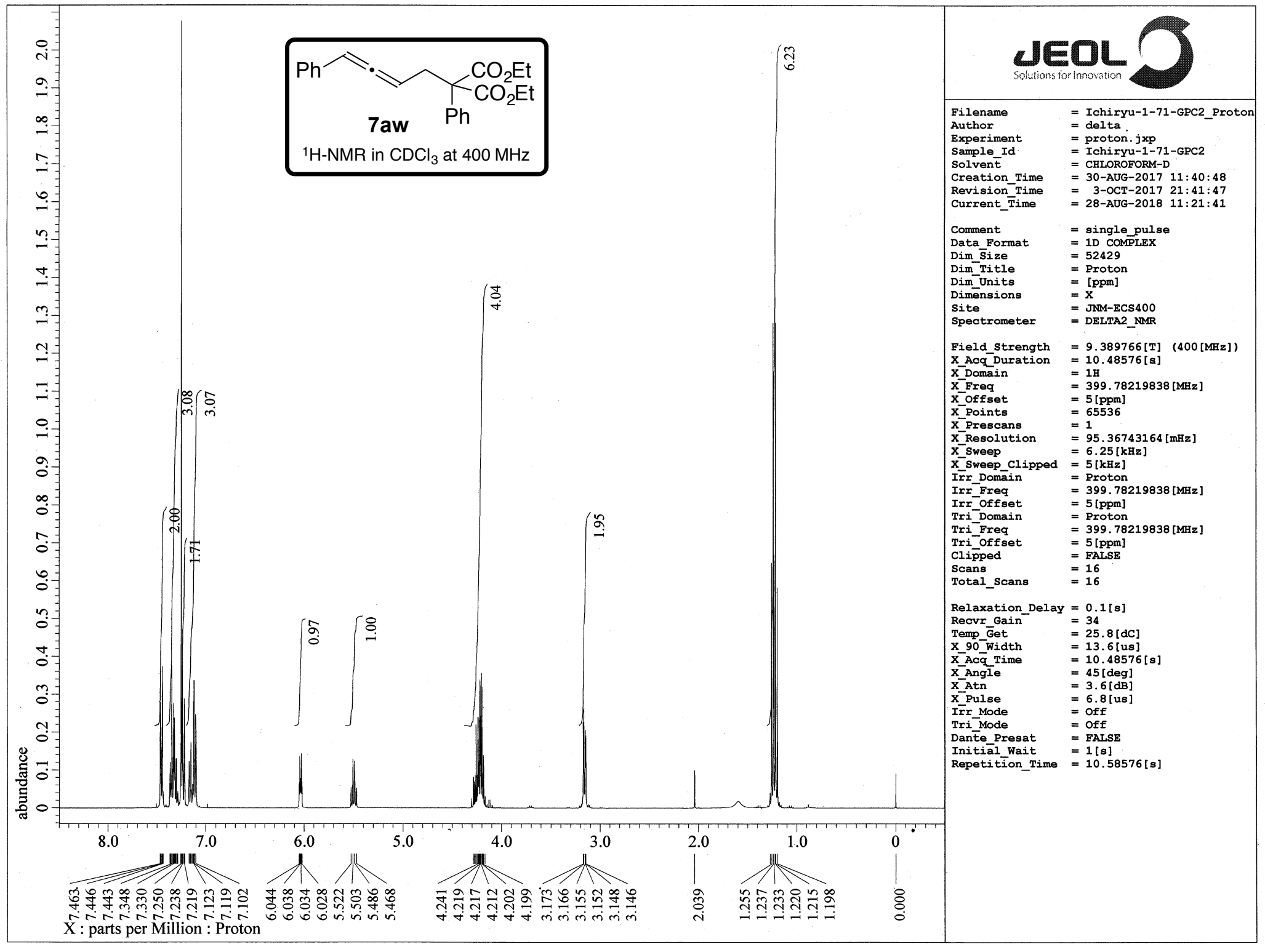

Figure S16. ${ }^{1} \mathrm{H}-\mathrm{NMR}$ Spectrum of 7aw in $\mathrm{CDCl}_{3}$ at $400 \mathrm{MHz}$. 


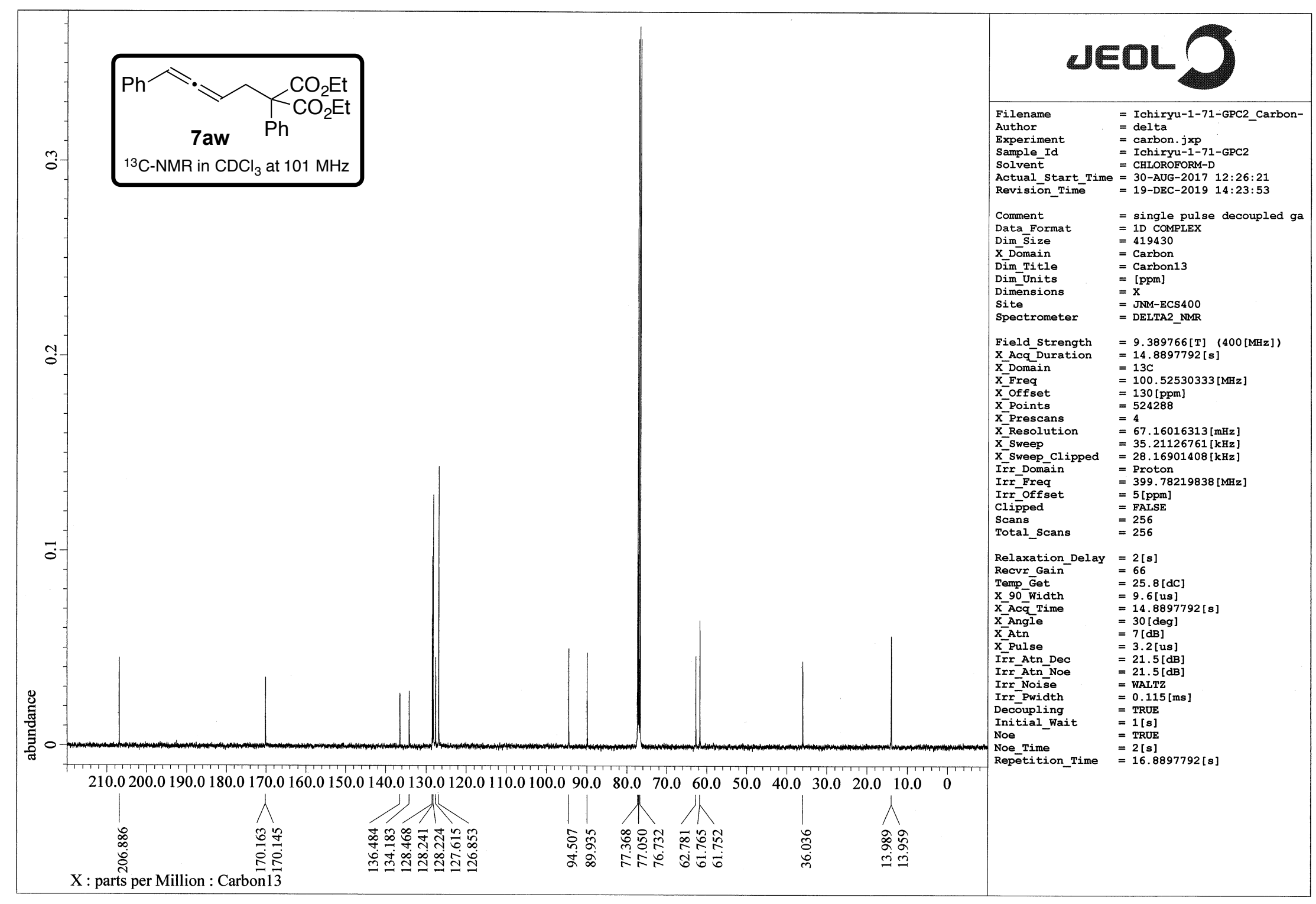

Figure S17. ${ }^{13} \mathrm{C}-\mathrm{NMR}$ Spectrum of $7 \mathbf{a w}$ in $\mathrm{CDCl}_{3}$ at $101 \mathrm{MHz}$. 


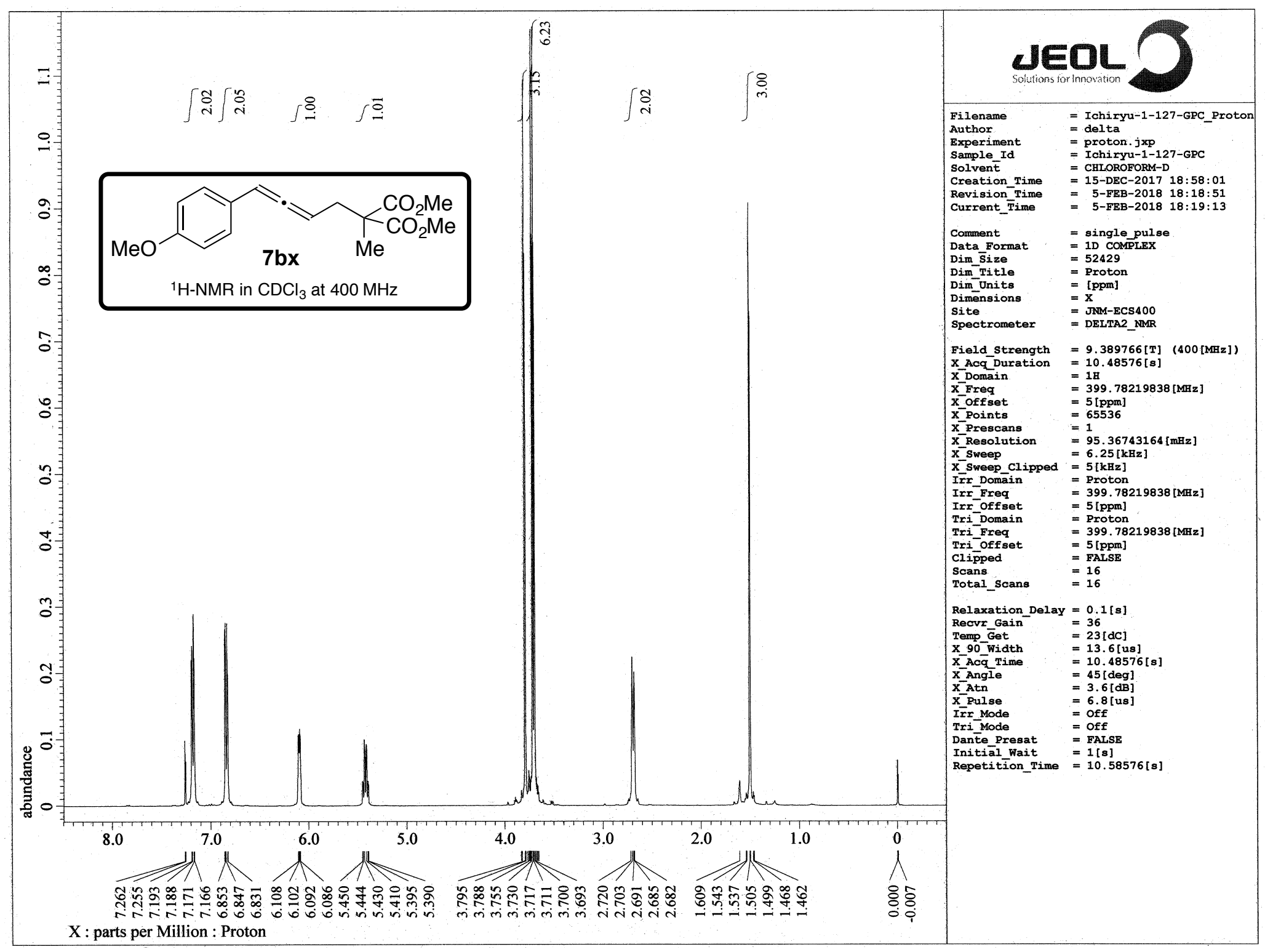

Figure S18. ${ }^{1} \mathrm{H}-\mathrm{NMR}$ Spectrum of $\mathbf{7 b x}$ in $\mathrm{CDCl}_{3}$ at $400 \mathrm{MHz}$. 


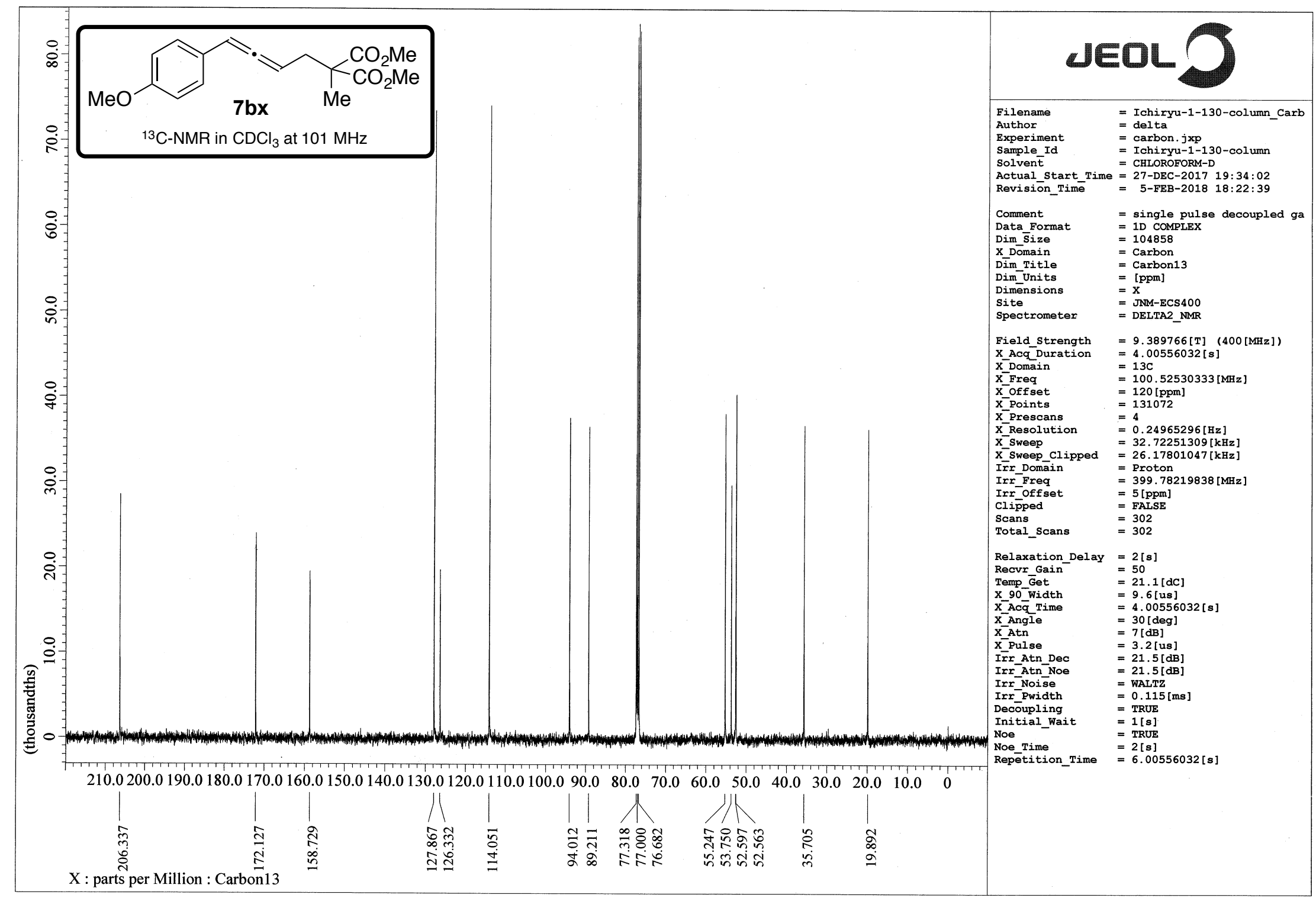

Figure S19. ${ }^{13} \mathrm{C}-\mathrm{NMR}$ Spectrum of $\mathbf{7 b x}$ in $\mathrm{CDCl}_{3}$ at $101 \mathrm{MHz}$. 


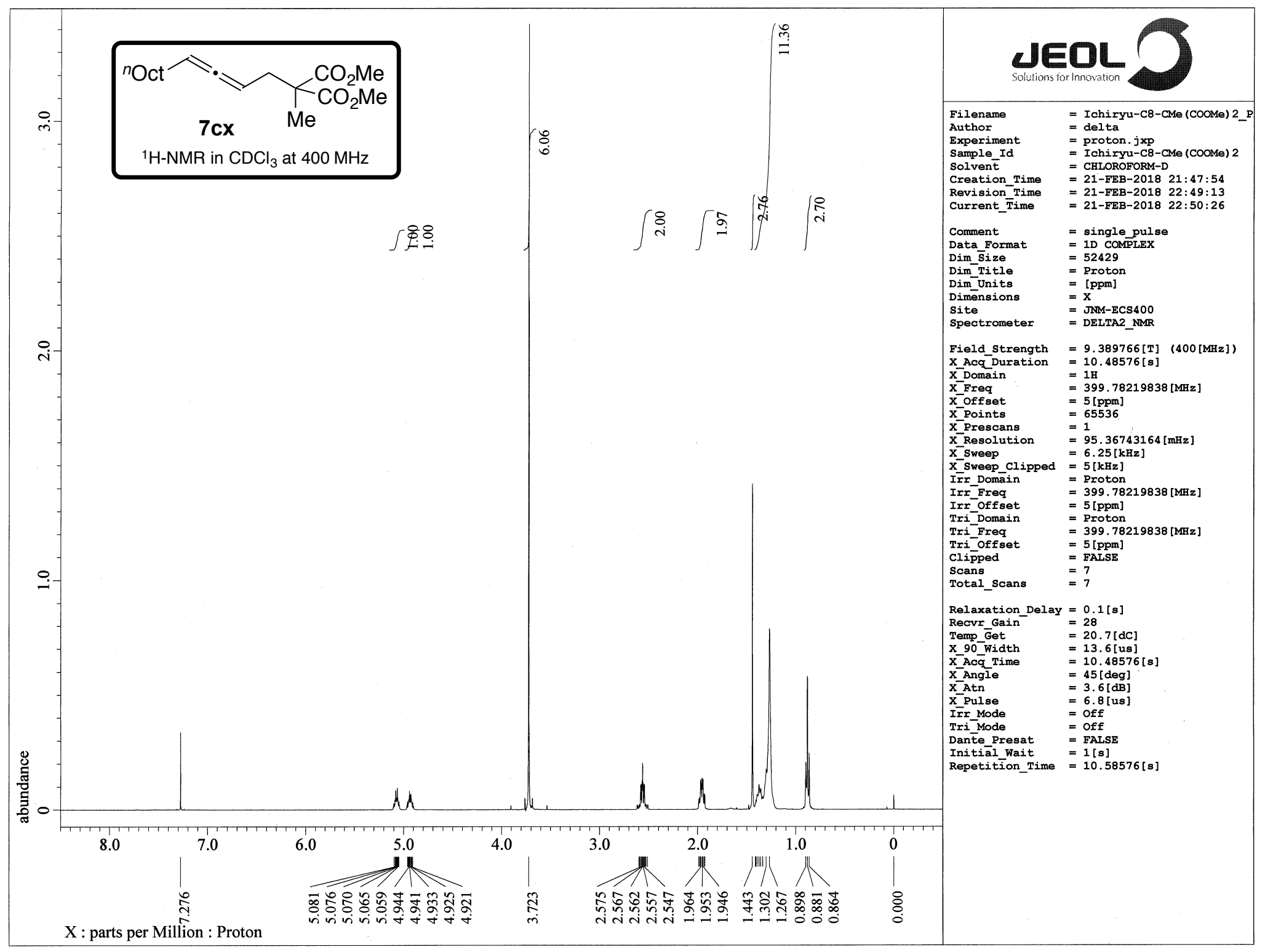

Figure S20. ${ }^{1} \mathrm{H}-\mathrm{NMR}$ Spectrum of $\mathbf{7} \mathbf{c x}$ in $\mathrm{CDCl}_{3}$ at $400 \mathrm{MHz}$. 


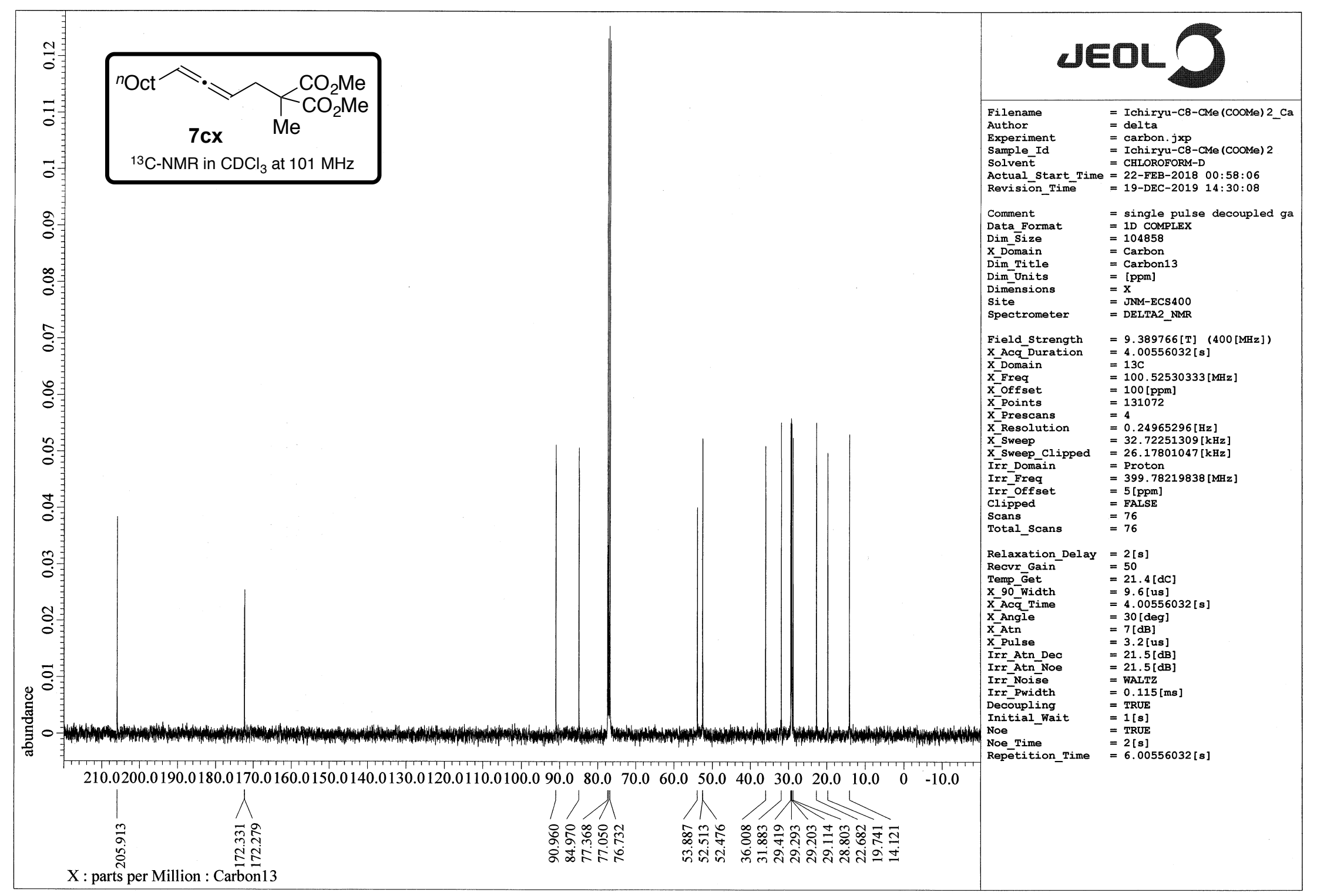

Figure S21. ${ }^{13} \mathrm{C}-\mathrm{NMR}$ Spectrum of $\mathbf{7} \mathbf{c x}$ in $\mathrm{CDCl}_{3}$ at $101 \mathrm{MHz}$. 


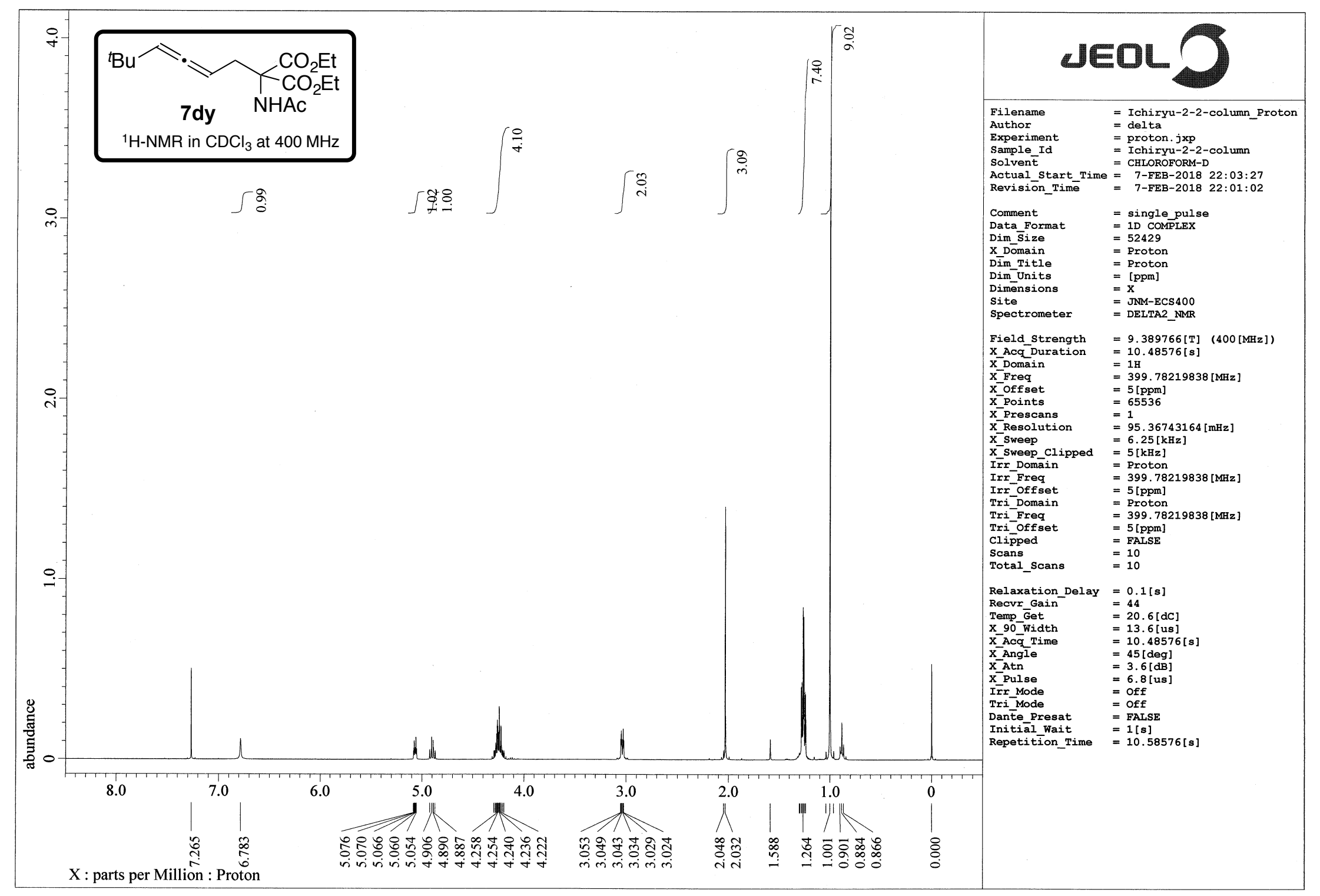

Figure S22. ${ }^{1} \mathrm{H}-\mathrm{NMR}$ Spectrum of $\mathbf{7 d y}$ in $\mathrm{CDCl}_{3}$ at $400 \mathrm{MHz}$. 


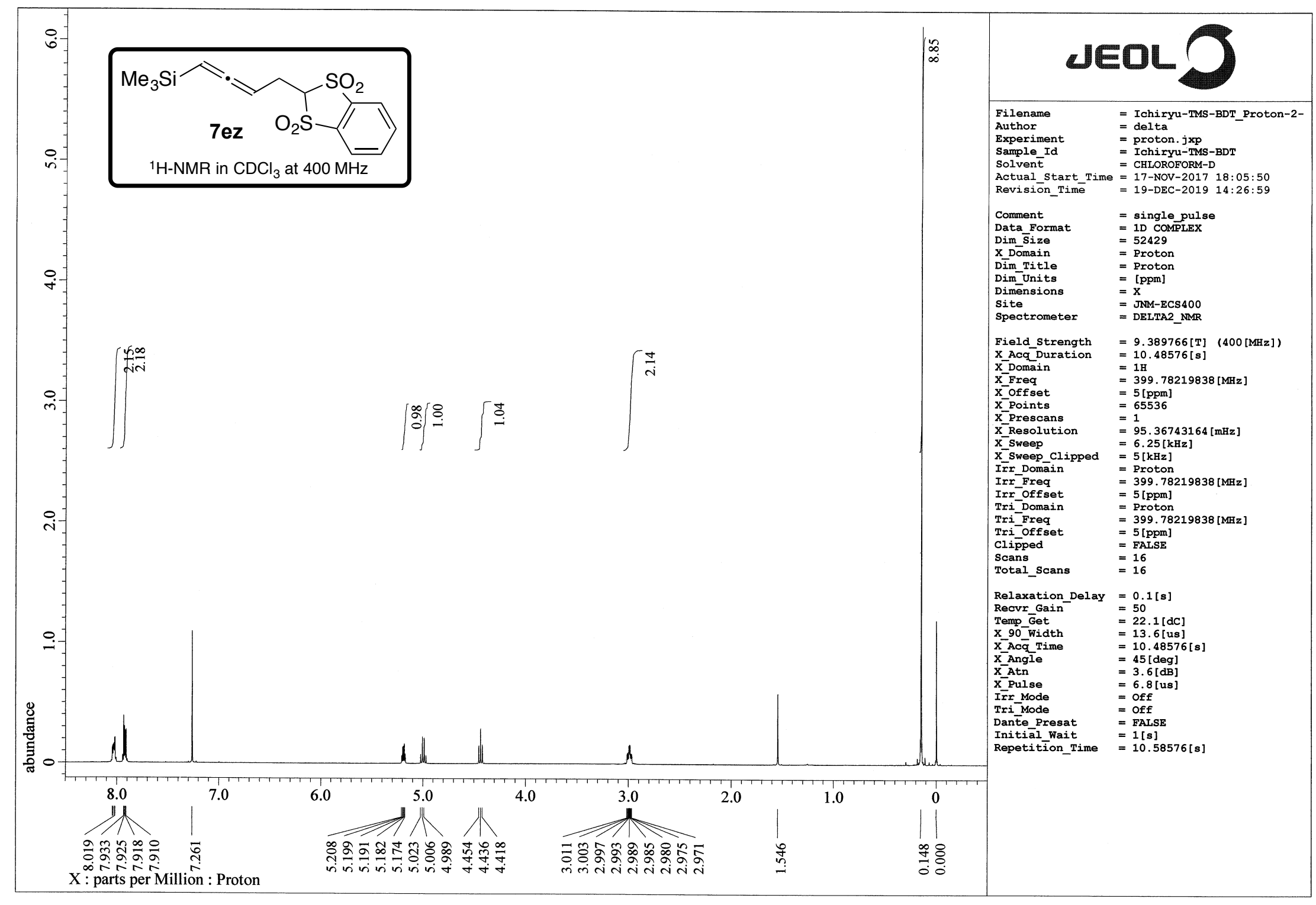

Figure S23. ${ }^{1} \mathrm{H}-\mathrm{NMR}$ Spectrum of $\mathbf{7 e z}$ in $\mathrm{CDCl}_{3}$ at $400 \mathrm{MHz}$. 


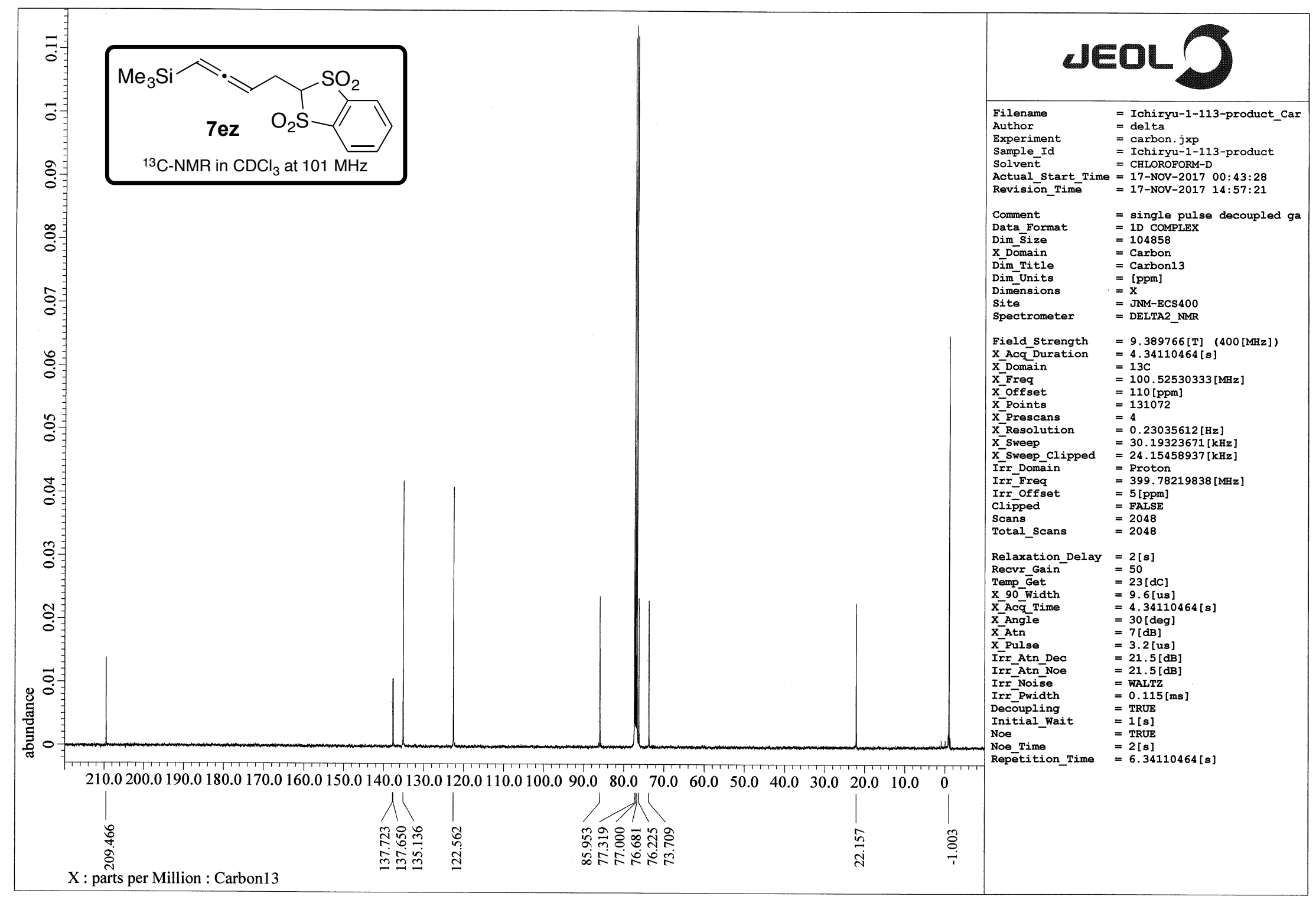

Figure S24. ${ }^{13} \mathrm{C}-\mathrm{NMR}$ Spectrum of $\mathbf{7 e z}$ in $\mathrm{CDCl}_{3}$ at $101 \mathrm{MHz}$. 


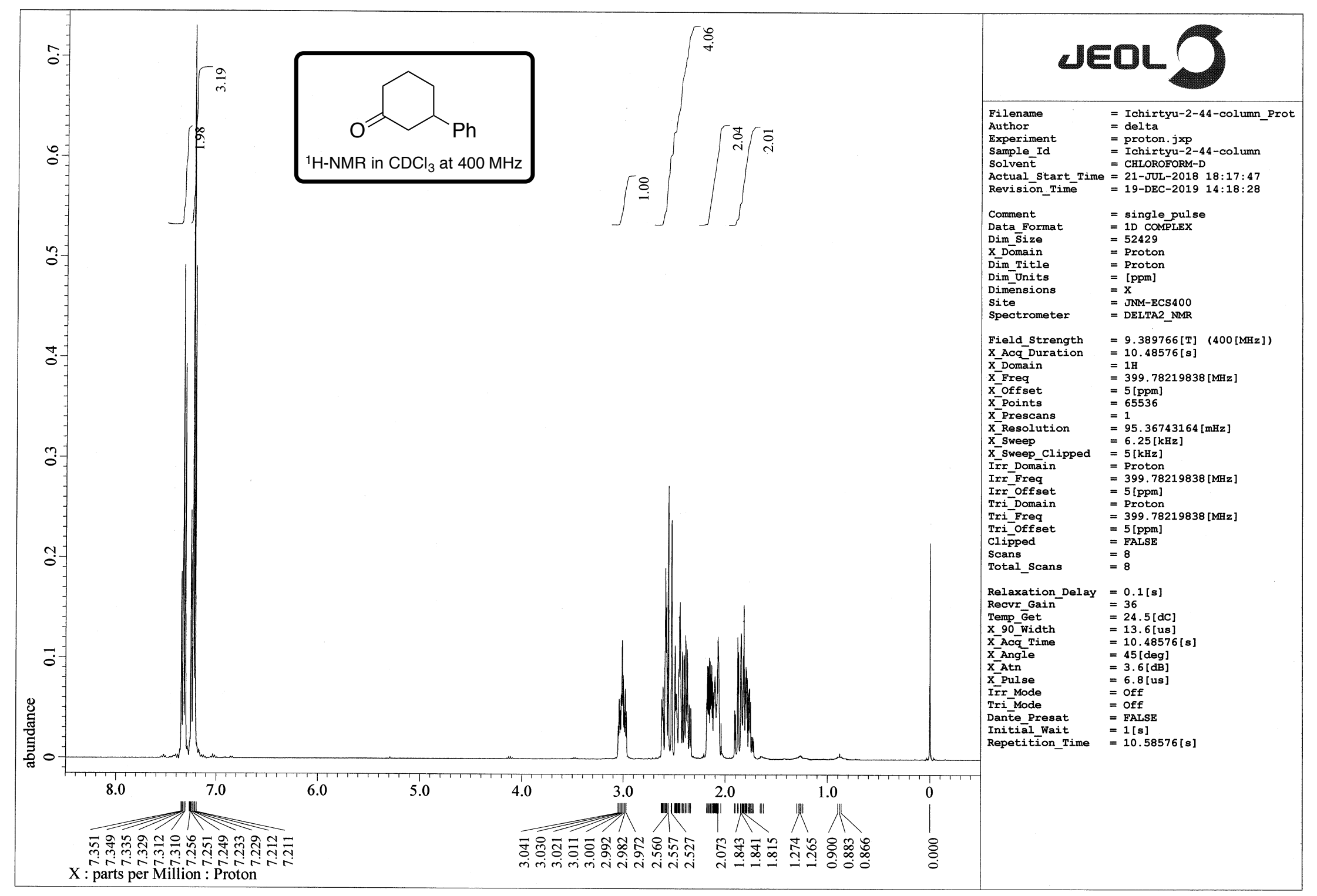

Figure S25. ${ }^{1} \mathrm{H}-\mathrm{NMR}$ Spectrum of 3-Phenylcyclohexanone in $\mathrm{CDCl}_{3}$ at $400 \mathrm{MHz}$. 
Figure S26. Chiral HPLC Analysis of 7aw (Table 1, entries 1-3); racemic (top); with (R)-Segphos (2nd); with $(R)$-DTBM-Segphos (3rd); with $(R)$-Fc-Segphos (bottom); Chiralpak AS-H; eluent: hexane $/{ }^{2} \mathrm{PrOH}=$ 500/1; flow rate: $0.5 \mathrm{~mL} / \mathrm{min}$.
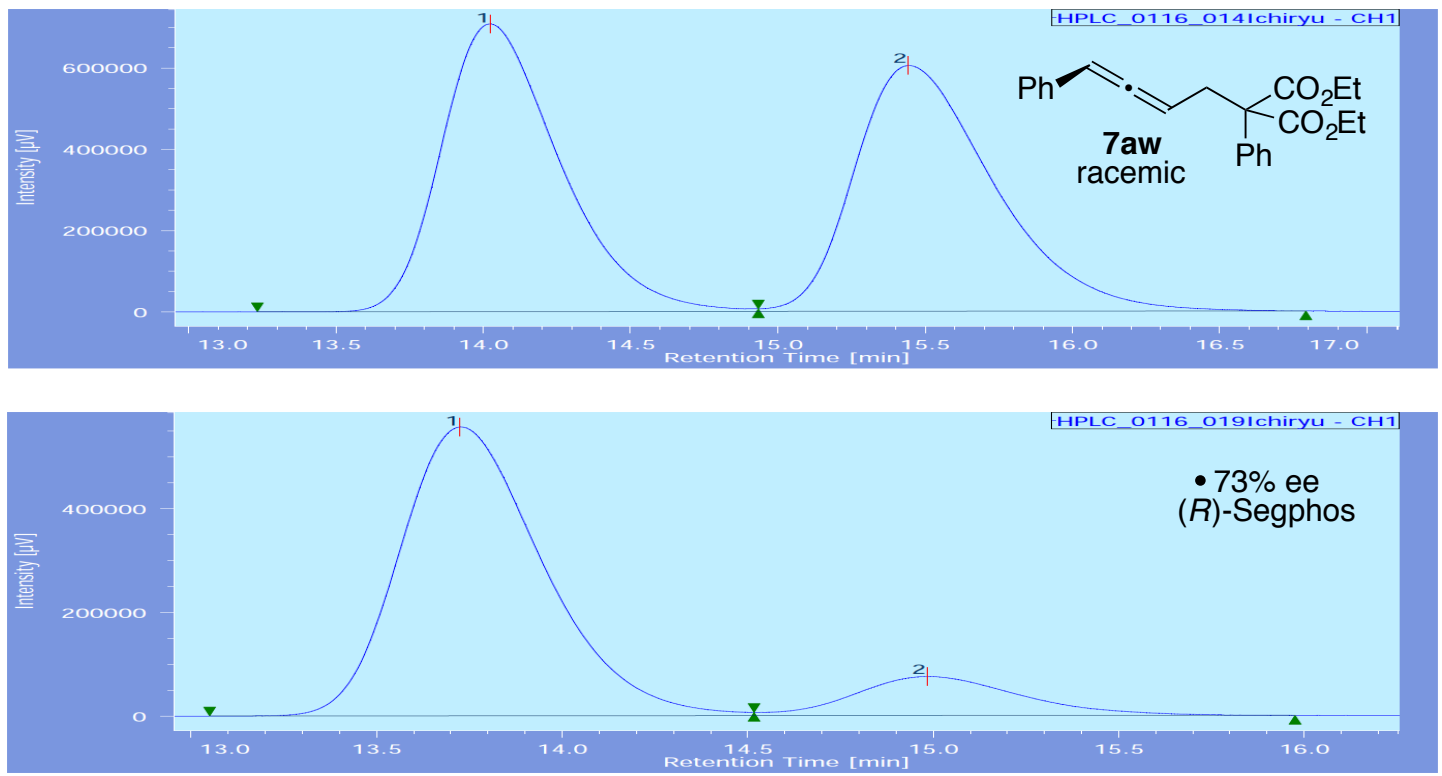

\begin{tabular}{|r|l|l|r|r|r|r|r|r|r|r|}
\hline$\#$ & peak name & CH & tR $[\mathrm{min}]$ & area $[\mu \mathrm{V} \cdot \mathrm{sec}]$ & height $[\mu \mathrm{V}]$ & area \% & height \% & NTP & resolution & symmetry coefficient \\
\hline 1 & $(R)$-isomer & 1 & 13.725 & 14940909 & 556937 & 86.481 & 88.098 & 6128 & 1.681 & 1.304 \\
\hline 2 & $(S)$-isomer & 1 & 14.983 & 2335636 & 75240 & 13.519 & 11.902 & 5613 & $\mathrm{~N} / \mathrm{A}$ & $\mathrm{N} / \mathrm{A}$ \\
\hline
\end{tabular}

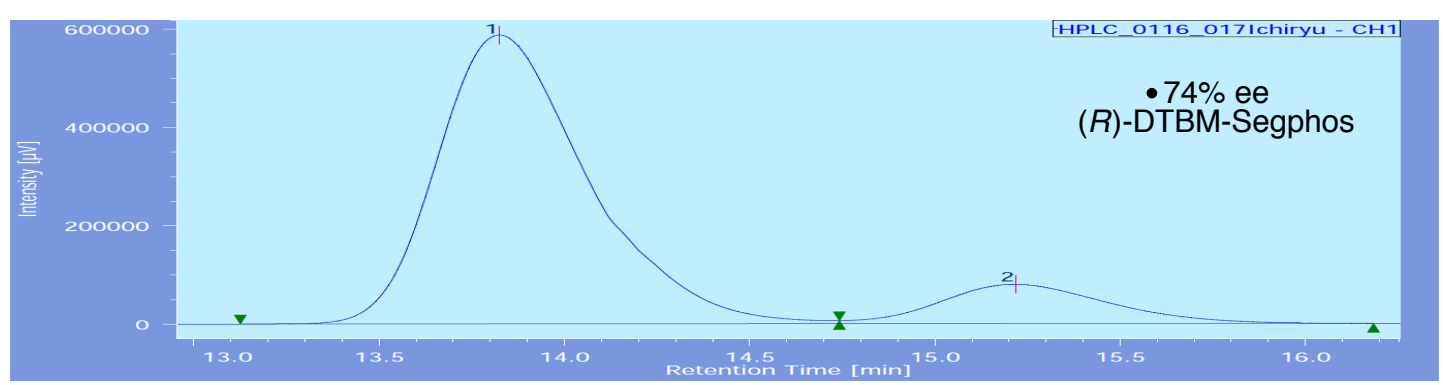

\begin{tabular}{|r|r|r|r|r|r|r|r|r|r|r|}
\hline$\#$ & peak name & CH & tR $[\mathrm{min}]$ & area $[\mu \mathrm{V} \cdot \mathrm{sec}]$ & height $[\mu \mathrm{V}]$ & area $\%$ & height \% & NTP & resolution & symmetry coefficient \\
\hline 1 & $(R)$-isomer & 1 & 13.825 & 16642421 & 537399 & 86.841 & 88.050 & 5888 & 1.807 & 1.363 \\
\hline 2 & $(S)$-isomer & 1 & 15.217 & 2521750 & 79717 & 13.159 & 11.950 & 5462 & $\mathrm{~N} / \mathrm{A}$ & $\mathrm{N} / \mathrm{A}$ \\
\hline
\end{tabular}

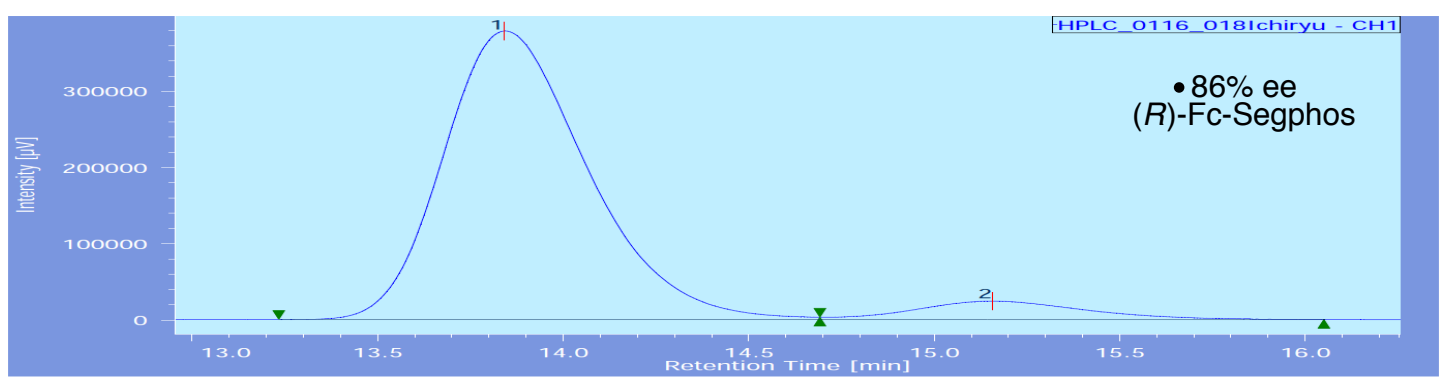

\begin{tabular}{|r|r|r|r|r|r|r|r|r|r|r|}
\hline$\#$ & peak name & CH & tR $[\mathrm{min}]$ & area $[\mu \mathrm{V} \cdot \mathrm{sec}]$ & height $[\mu \mathrm{V}]$ & area \% & height \% & NTP & resolution & symmetry coefficient \\
\hline 1 & $(R)$-isomer & 1 & 13.842 & 10214295 & 378402 & 93.112 & 94.066 & 6198 & 1.736 & 1.286 \\
\hline 2 & $(S)$-isomer & 1 & 15.158 & 755567 & 23869 & 6.888 & 5.934 & 5504 & $\mathrm{~N} / \mathrm{A}$ & $\mathrm{N} / \mathrm{A}$ \\
\hline
\end{tabular}


Figure S27. Chiral HPLC Analysis of 7bx (Table 1, entries 4 and 5); racemic (top); with (R)-Segphos (middle); with $(R)-\mathrm{Fc}-\mathrm{Segphos}$ (bottom); Chiralpak AD-H; eluent: hexane $/{ }^{i} \mathrm{PrOH}=20 / 1$; flow rate: 0.8 $\mathrm{mL} / \mathrm{min}$.
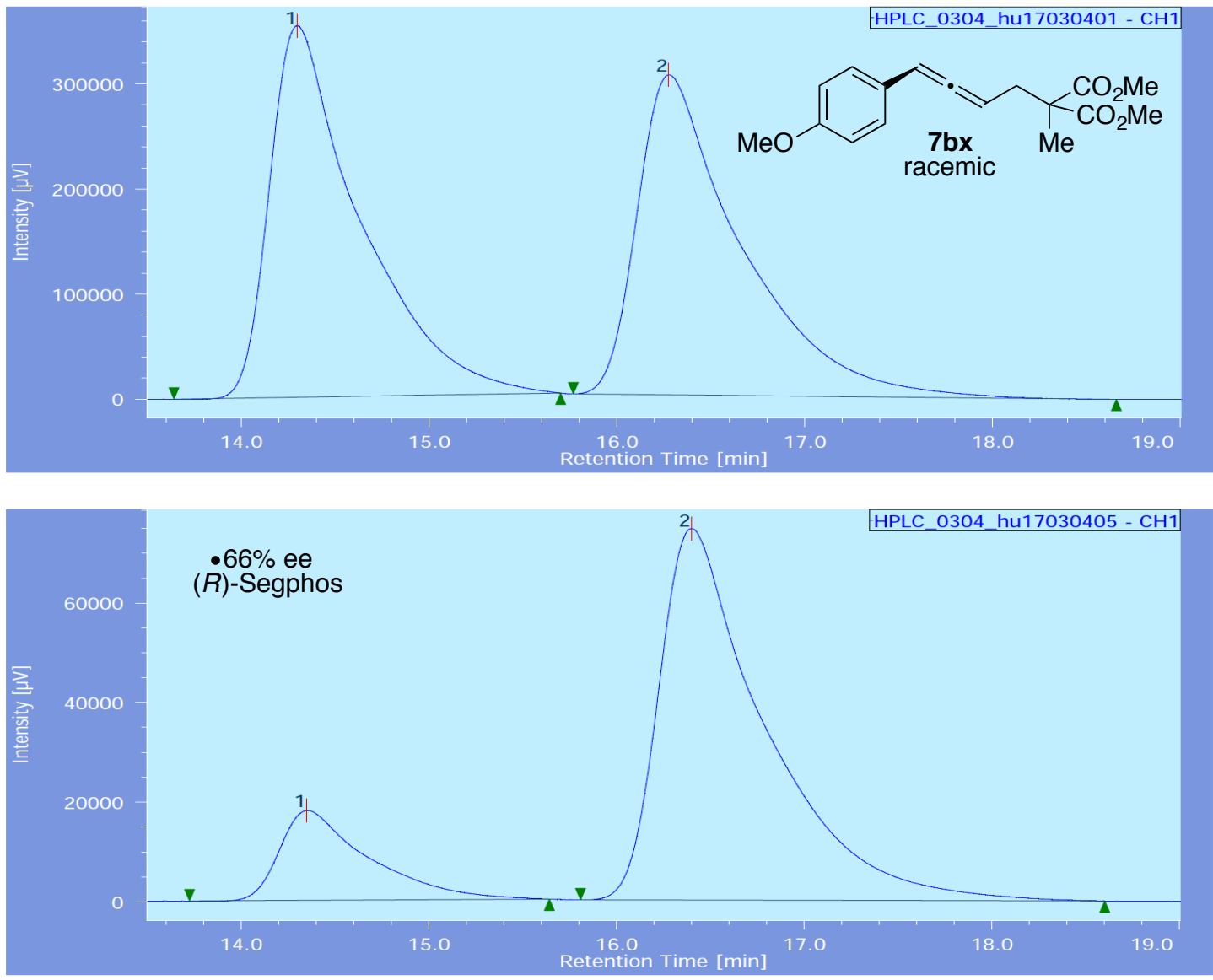

\begin{tabular}{|r|l|r|r|r|r|r|r|r|r|r|}
\hline$\#$ & peak name & CH & tR $[\mathrm{min}]$ & area $[\mu \mathrm{V}$ •sec $]$ & height $[\mu \mathrm{V}]$ & area \% & height \% & NTP & resolution & symmetry coefficient \\
\hline 1 & $(S)$-isomer & 1 & 14.350 & 612894 & 18166 & 17.150 & 19.539 & 5168 & 2.366 & 2.137 \\
\hline 2 & $(R)$-isomer & 1 & 16.400 & 2960873 & 74807 & 82.850 & 80.461 & 4877 & $\mathrm{~N} / \mathrm{A}$ & 2.078 \\
\hline
\end{tabular}

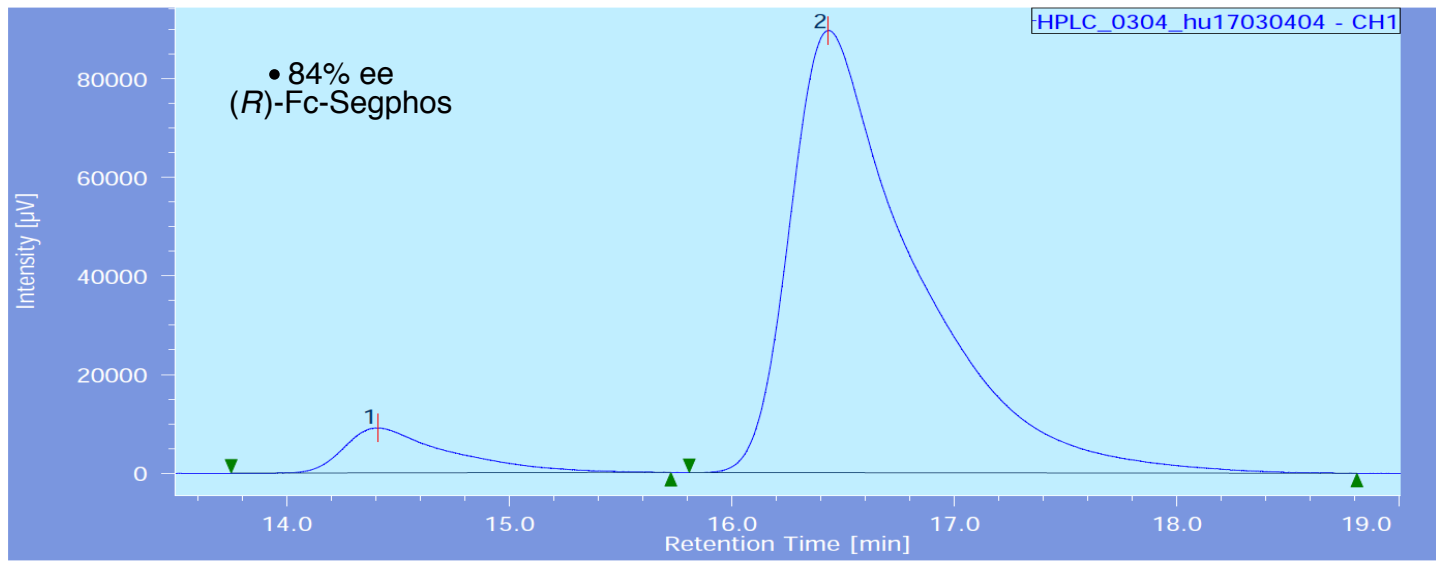

\begin{tabular}{|r|l|r|r|r|r|r|r|r|r|r|}
\hline$\#$ & peak name & CH & tR $[\mathrm{min}]$ & area $[\mu \mathrm{V}$ •sec $]$ & height $[\mu \mathrm{V}]$ & area \% & height \% & NTP & resolution & symmetry coefficient \\
\hline 1 & $(S)$-isomer & 1 & 14.408 & 305870 & 9155 & 7.993 & 9.261 & 5230 & 2.353 & 2.060 \\
\hline 2 & $(R)$-isomer & 1 & 16.433 & 3520890 & 89701 & 92.007 & 90.739 & 5007 & $\mathrm{~N} / \mathrm{A}$ & 2.095 \\
\hline
\end{tabular}


Figure S28. Chiral HPLC Analysis of 7cx (Table 1, entries 6 and 7); racemic (top); with (R)-Segphos (middle); with $(R)-\mathrm{Fc}-\mathrm{Segphos}$ (bottom); Chiralpak IB; eluent: hexane $/ \mathrm{PrOH}=600 / 1$; flow rate: 0.25 $\mathrm{mL} / \mathrm{min}$.
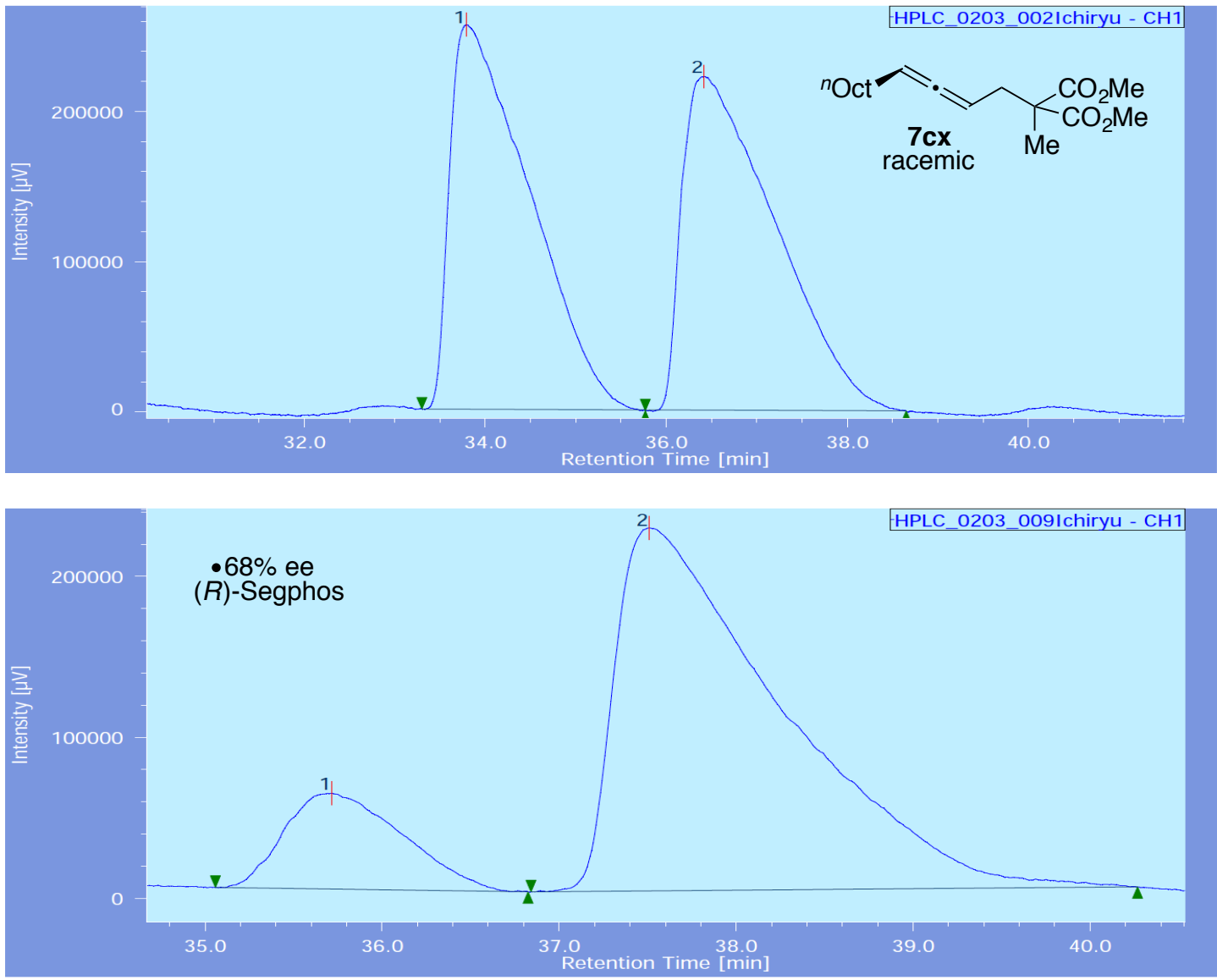

\begin{tabular}{|r|r|r|r|r|r|r|r|r|r|r|}
\hline$\#$ & peak name & CH & tR $[\mathrm{min}]$ & area $[\mu \mathrm{V}$ •sec $]$ & height $[\mu \mathrm{V}]$ & area \% & height \% & NTP & resolution & symmetry coefficient \\
\hline 1 & $(S)$-isomer & 1 & 35.717 & 2758981 & 59395 & 15.846 & 20.852 & 12202 & 1.226 & 1.337 \\
\hline 2 & $(R)$-isomer & 1 & 37.508 & 14652066 & 225439 & 84.154 & 79.148 & 8410 & $\mathrm{~N} / \mathrm{A}$ & 3.029 \\
\hline
\end{tabular}

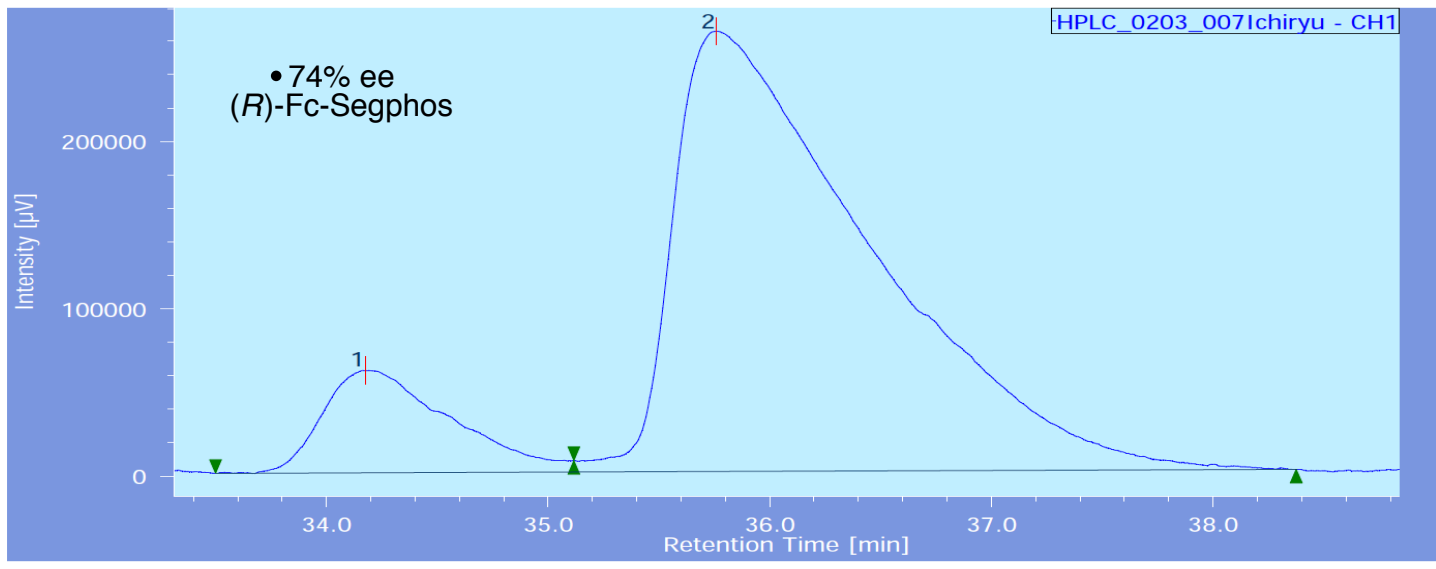

\begin{tabular}{|r|r|r|r|r|r|r|r|r|r|r|}
\hline$\#$ & peak name & CH & tR $[\mathrm{min}]$ & area $[\mu \mathrm{V} \cdot$ sec $]$ & height $[\mu \mathrm{V}]$ & area \% & height \% & NTP & resolution & symmetry coefficient \\
\hline 1 & $(S)$-isomer & 1 & 34.175 & 2452017 & 61175 & 13.113 & 18.862 & 16479 & 1.207 & $\mathrm{~N} / \mathrm{A}$ \\
\hline 2 & $(R)$-isomer & 1 & 35.758 & 16247123 & 263159 & 86.887 & 81.138 & 8353 & $\mathrm{~N} / \mathrm{A}$ & 2.794 \\
\hline
\end{tabular}


Figure S29. Chiral HPLC Analysis of 7dy (Table 1, entries 8 and 9); racemic (top); with (R)-Segphos (middle); with $(R)$-Fc-Segphos (bottom); Chiralpak IA; eluent: hexane $/{ }^{i} \mathrm{PrOH}=20 / 1$; flow rate: 0.5 $\mathrm{mL} / \mathrm{min}$.
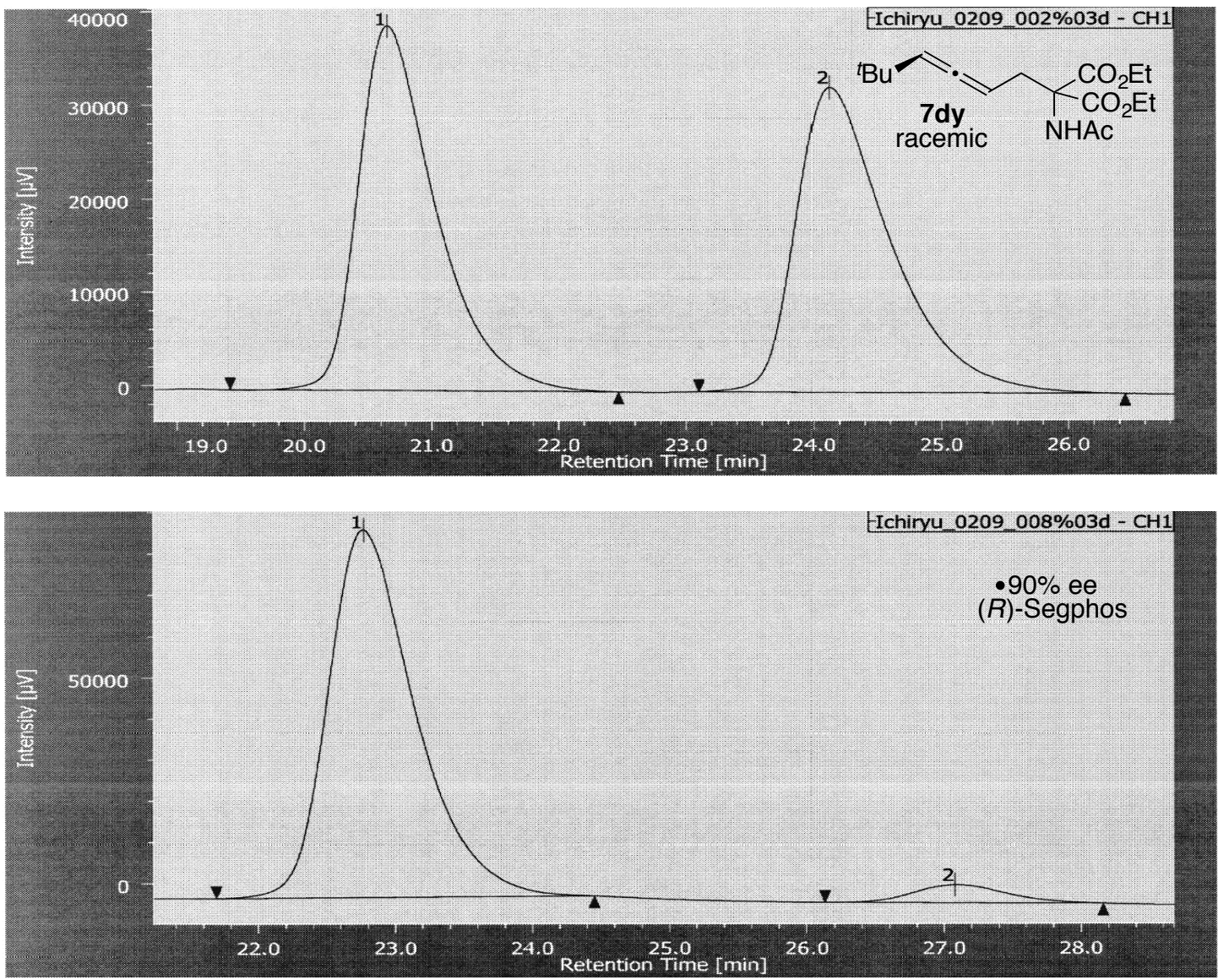

\begin{tabular}{|r|r|r|r|r|r|r|r|r|r|r|}
\hline$\#$ & peak name & CH & tR $[\mathrm{min}]$ & area $[\mu \mathrm{V} \cdot \mathrm{sec}]$ & height $[\mu \mathrm{V}]$ & area \% & height \% & NTP & resolution & symmetry coefficient \\
\hline 1 & $(R)$-isomer & 1 & 22.767 & 3934918 & 89050 & 95.015 & 95.319 & 6519 & 3.632 & 1.392 \\
\hline 2 & $(S)$-isomer & 1 & 27.075 & 206431 & 4373 & 4.985 & 4.681 & 7493 & $\mathrm{~N} / \mathrm{A}$ & 1.180 \\
\hline
\end{tabular}

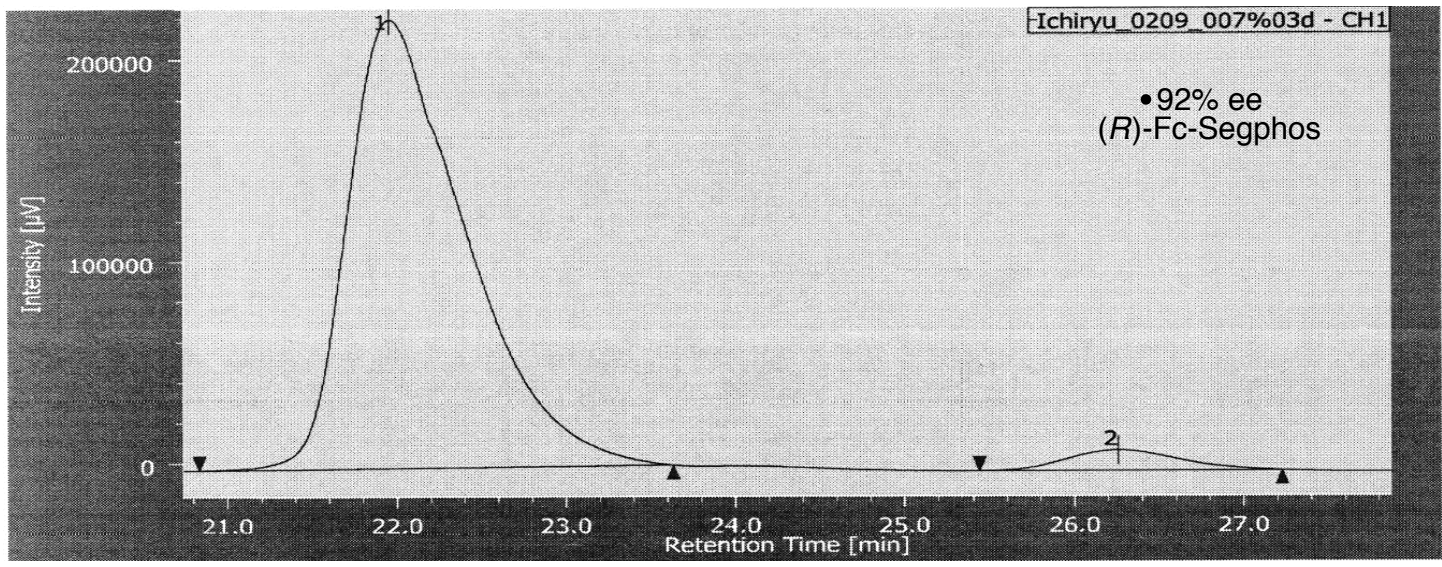

\begin{tabular}{|r|r|r|r|r|r|r|r|r|r|r|}
\hline$\#$ & peak name & $\mathrm{CH}$ & $\mathrm{tR}[\mathrm{min}]$ & area $[\mu \mathrm{V} \cdot \mathrm{sec}]$ & height $[\mu \mathrm{V}]$ & area \% & height \% & NTP & resolution & symmetry coefficient \\
\hline 1 & $(R)$-isomer & 1 & 21.958 & 10769242 & 221876 & 95.936 & 95.664 & 4769 & 3.465 & 1.629 \\
\hline 2 & $(S)$-isomer & 1 & 26.258 & 456153 & 10056 & 4.064 & 4.336 & 7449 & $\mathrm{~N} / \mathrm{A}$ & 1.163 \\
\hline
\end{tabular}


Figure S30. Chiral HPLC Analysis of 7ez (Table 1, entries 10 and 11); racemic (top); with (R)-Segphos (middle); with $(R)$-Fc-Segphos (bottom); Chiralpak IB; eluent: hexane $/{ }^{2} \mathrm{PrOH}=20 / 1$; flow rate: 1.0 $\mathrm{mL} / \mathrm{min}$.
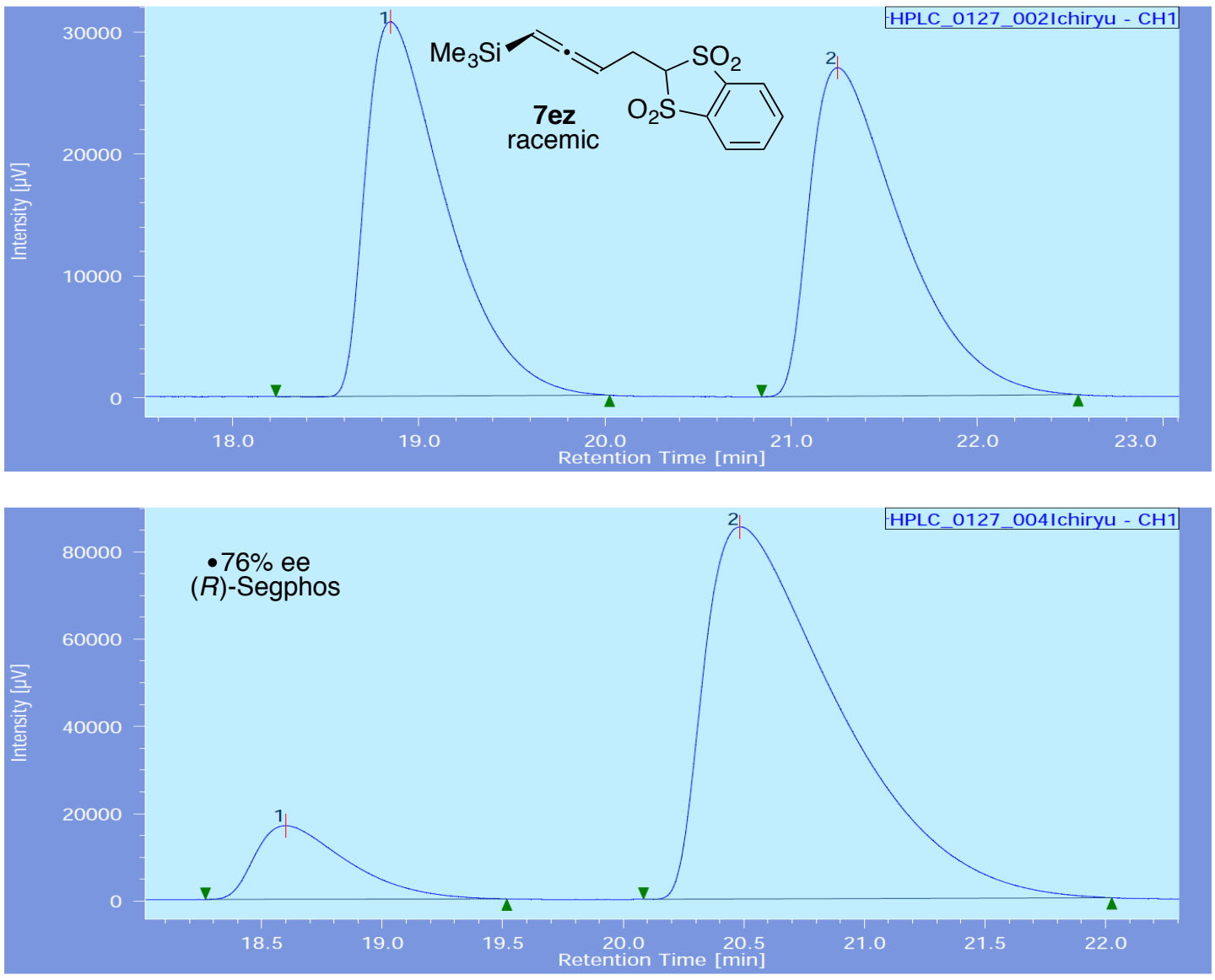

\begin{tabular}{|r|l|r|r|r|r|r|r|r|r|r|}
\hline$\#$ & peak name & CH & tR $[\mathrm{min}]$ & area $[\mu \mathrm{V}$ •sec $]$ & height $[\mu \mathrm{V}]$ & area \% & height \% & NTP & resolution & symmetry coefficient \\
\hline 1 & $(S)$-isomer & 1 & 18.600 & 446950 & 16864 & 11.893 & 16.517 & 11565 & 2.220 & 1.872 \\
\hline 2 & $(R)$-isomer & 1 & 20.483 & 3311201 & 85233 & 88.107 & 83.483 & 6585 & $\mathrm{~N} / \mathrm{A}$ & 2.508 \\
\hline
\end{tabular}

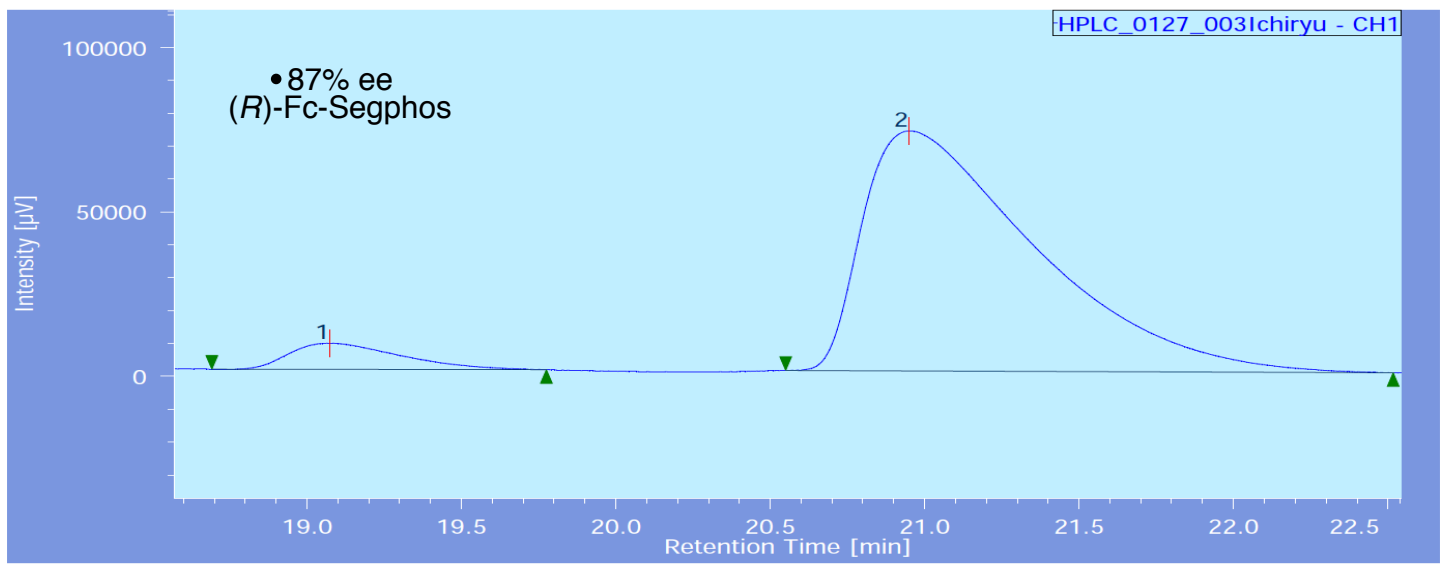

\begin{tabular}{|r|l|c|r|r|r|r|r|r|r|r|}
\hline$\#$ & peak name & $\mathrm{CH}$ & $\mathrm{tR}[\mathrm{min}]$ & area $[\mu \mathrm{V} \cdot \mathrm{sec}]$ & height $[\mu \mathrm{V}]$ & area \% & height \% & NTP & resolution & symmetry coefficient \\
\hline 1 & $(S)$-isomer & 1 & 19.075 & 197260 & 7941 & 6.503 & 9.818 & 13341 & 2.251 & 1.593 \\
\hline 2 & $(R)$-isomer & 1 & 20.950 & 2836090 & 72945 & 93.497 & 90.182 & 6886 & $\mathrm{~N} / \mathrm{A}$ & 2.423 \\
\hline
\end{tabular}


Figure S31. Chiral HPLC Analysis of 2a (Scheme 2); racemic 2a (top), $(R)-(-)-2 a$ (bottom); chiral column: Chiralcel OD-H; eluent: hexane $/{ }^{2} \mathrm{PrOH}=100 / 1$; flow rate: $0.8 \mathrm{~mL} / \mathrm{min}$.
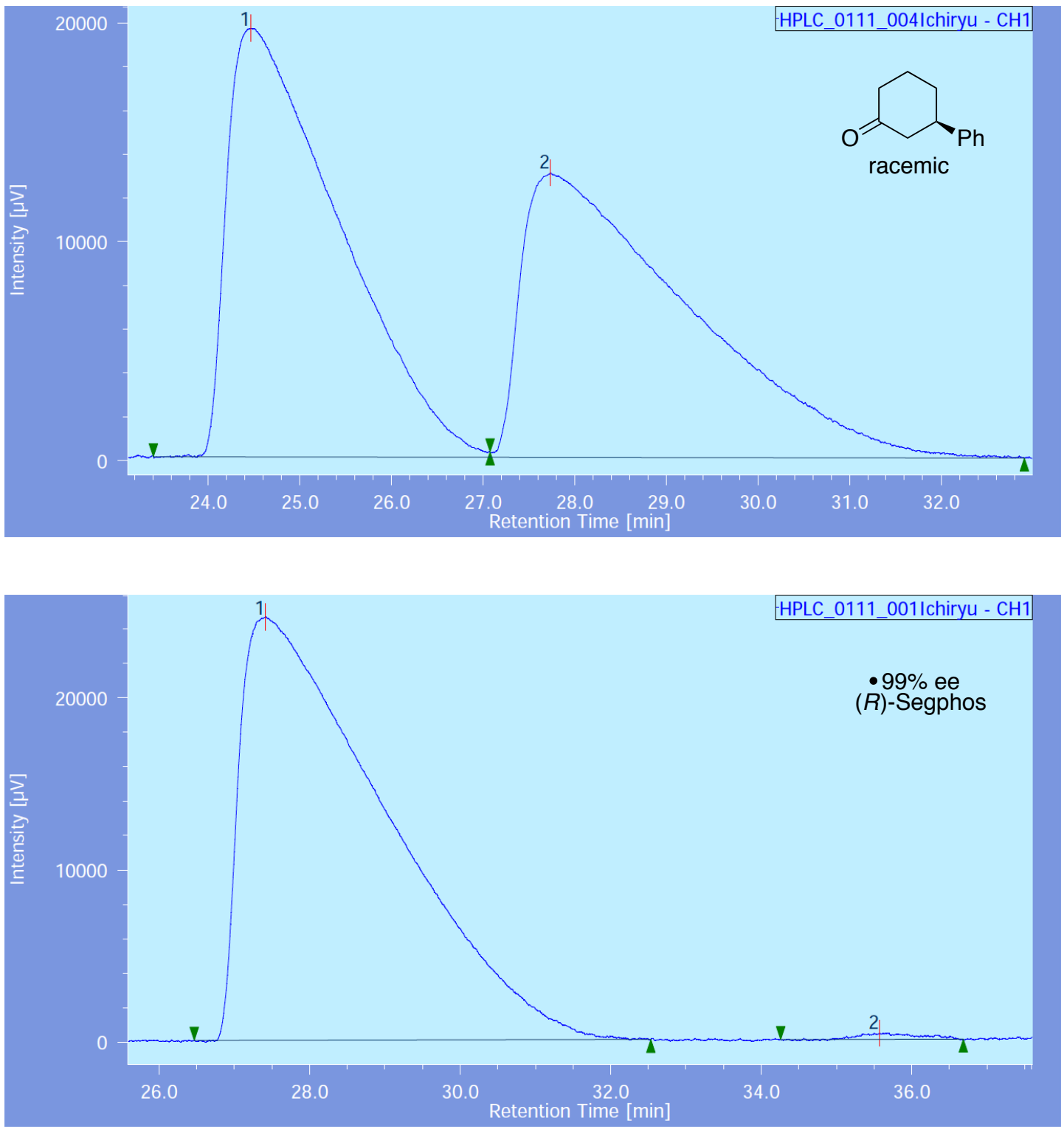

\begin{tabular}{|l|l|c|r|r|r|r|r|r|r|r|}
\hline$\#$ & peak name & CH & tR $[\mathrm{min}]$ & area $[\mu \mathrm{V} \cdot$ sec $]$ & height $[\mu \mathrm{V}]$ & area \% & height \% & NTP & resolution & symmetry coefficient \\
\hline 1 & $(S)$-isomer & 1 & 27.417 & 3294550 & 24592 & 99.382 & 98.517 & 917 & 2.858 & 3.799 \\
\hline 2 & $(R)$-isomer & 1 & 35.575 & 20481 & 370 & 0.618 & 1.483 & 4580 & $\mathrm{~N} / \mathrm{A}$ & 0.923 \\
\hline
\end{tabular}

